Copyright (C) 2018 by Academic Publishing House Researcher

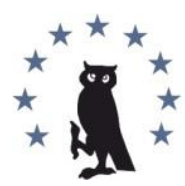

Published in the Russian Federation

European Researcher. Series A

Has been issued since 2010.

ISSN 2219-8229

E-ISSN 2224-0136

2018, 9(2): 78-106

DOI: 10.13187/er.2018.2.78

www.erjournal.ru

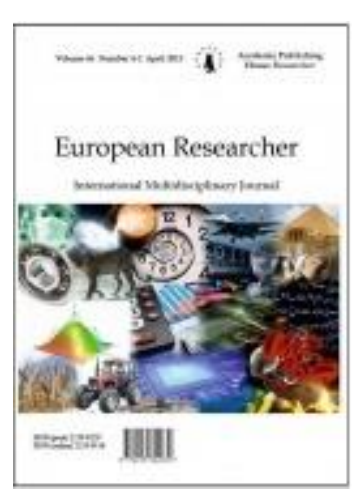

\title{
Image of France and French People in the Soviet and Russian Screens
}

\author{
Alexander Fedorov a, * \\ a Rostov State University of Economics, Russian Federation
}

\begin{abstract}
Object of study: the development of the theme of the image of France and French people in the Soviet and Russian screens. Subject of research: the evolution of the basic concepts and ideological stereotypes theme image of France and French people in the Soviet and Russian screens.

Research objectives: to determine the place and role of the theme of the image of France and French people in the Soviet film industry compared with the trends of the Russian modern era; to study the cinematic, political, ideological, social, cultural context, the main stages of the project stated theme, direction, goals, objectives, concept interpretation of this topic in the Soviet and Russian screens; to carry out a comparative analysis of classification and ideology, content models, modifications of the genre, Soviet and Russian cinema stereotypes associated with the interpretation of the image of France and French people.

As for the statistical data, it can be noted that the Russian cinematographers' attention to the French theme has increased significantly (about twice) in the post-Soviet period. So for the Soviet years, 128 films with French characters were staged, where as in the last 26 years (1992-2018) of such films 78 have been removed. With the dominance of the drama ( 75 drams in the Soviet period and 25 in the post-Soviet period), the share of films melodramatic genre (from 14 in the Soviet period to 20 - in the post-Soviet).

Consequently, interest in French subjects in Soviet and Russian cinema is not accidental, which is understandable - the history of Russia and France is closely connected, and this is not only the history of wars, but also friendship, mutual attraction of cultures.

Keywords: image, France, French, USSR, Russia, screen, cinema, film, cold war, confrontation, media culture, media text.

\section{1. Введение}

Научная проблема, на решение которой направлен проект, вытекает из противоречия между подробной научной разработанностью политологических аспектов тематики взаимоотношений СССР/России и Запада (Наринский, 2006; Невежин, 1999; Немкина, 2005; Рукавишников, 2000; Уткин, 2005; Фатеев, 1999; Шенин, 2003; LaFeber, 1990; Levering, 1982; Robin, 2001; Westad, 2007 и др.) и недостаточным вниманием исследователей к сравнительному анализу эволюции образа Франции и французов на советском и российском экранах.
\end{abstract}

\footnotetext{
${ }^{*}$ Corresponding author

E-mail addresses: 1954alex@mail.ru (A. Fedorov)
} 
Основную научную значимость решения проблемы исследования мы видим в том, что нами будет проанализирован и структурирован образ Франции и французов, увиденный советским, а затем и российским «киновзглядом».

В целях ограничения аудиовизуального материала исследования мы ограничились только игровыми фильмами (имеющими самое широкое распространение и сильное влияние на массовую аудиторию), не включая в спектр анализа документальные, анимационные фильмы, телевизионные передачи.

\section{2. Материалы и методы исследования}

Материал нашего исследования - российские и советские фильмы, затрагивающие тематику Франции и французов. Основной метод - герменевтический анализ данных фильмов (включая: анализ стереотипов, идеологический анализ, идентификационный анализ, иконографический анализ, сюжетный анализ, анализ характеров персонажей и др. (Лотман, 1973; Эко, 1976; 1998; Potter, 2001; Siverblatte, 2001).

Цель: раскрыть особенности, определить место, роль, идеологическую значимость темы образа Франции и французов на советском и российском экранах. Объект исследования - процесс развития темы образа Франции и французов на советском и российском экранах. Предмет исследования - эволюция основных идеологических концепций и кинематографических стереотипов темы образа Франции и французов на советском и российском экранах. Задачи: определить место и роль темы образа Франции и французов в отечественном кинематографе; изучить кинематографический, политический, идеологический, социокультурный контекст, основные этапы развития заявленной в проекте темы, направления, цели, задачи, авторские концепции трактовки данной темы на советском и российском экранах; осуществить классификацию и сравнительный анализ идеологии, моделей содержания, модификаций жанра, кинематографических стереотипов отечественного кинематографа, связанного с трактовками образа Франции и французов.

\section{3. Обсуждение}

Исследование политических, идеологических, исторических, социокультурных аспектов противостояния СССР/России и Запада довольно часто становились предметом исследования (Баскаков, 1981; Волкогонов, 1983; Гудков, 2005; Рукавишников, 2000; Keen, 1986; Lafeber, 1990; Levering, 1982; Whitfield, 1991 и др.). Что же касается трактовки образа Франции и французов на отечественном экране, то, исходя из исследований отечественных и зарубежных ученых (Зоркая, 2005; Климонтович, 1990; Колесникова, 2007; 2008; 2010; Стишова, Сививля, 2003; Туровская, 1993; 1996; 2003; Икшеещтб 2006; Dubois, 2007; Douglas, 2001; Fried, 1998; Haynes, 1966; Keen, 1986; Kenez, 1992; Lacourbe, 1985; Lauren, 2000; Lawton, 2004; Reid, 2006; Rubenstein, 1979; Shaw and Youngblood, 2010; Shaw, 2008; Shlapentokh, 1993; Small, 1980; Strada and Troper, 1997; Strada, 1989; Turovskaya, 1993 и др.), можно заключить, что аспект сравнительного анализа киноведческих, социокультурных, политических, идеологических аспектов развития темы образа Франции и французов на советском и российском экранах все еще остается малоизученным.

\section{4. Результаты}

Несмотря на серьезные межгосударственные конфликты (достигшие пика в эпоху наполеоновских войн), образ Франции и французов для россиян всегда был притягательно романтизирован. И здесь кинематограф, разумеется, не был исключением. Советский кинематограф 1920-1930-х попытался синтезировать романтический образ Франции с революционным пафосом («Новый Вавилон», «Мирабо», «События в Сен-Луи», «Зори Парижа», «Юные коммунары», «Гаврош»), что не мешало, впрочем, в «Обреченных» (1930) развернуть на экране мелодраматическую историю любви француженки и русского солдата. Даже в фильмах о военном противостоянии Франции и России французские персонажи во многих случаях выглядели достойными противниками. Именно так, например, выглядело соперничество русского и французского летчиков в драме «Крылья» (1932). Линия Франции как достойного военного противника, на сей раз в эпоху наполеоновских войн, была продолжена и в советских фильмах 1960-х - 1980-х годов («Война и мир», «Ватерлоо», «Әскадрон гусар летучих», «Багратион»). С уважением были показаны в советском кино и 
выдающиеся деятели французской культуры («Третья молодость», «Ошибка Оноре де Бальзака», «Дюма на Кавказе», «Жизнь Берлиоза»).

Большой успех у советских зрителей имела экранизированная М. Роммом новелла Ги де Мопассана «Пышка», намекавшая, разумеется, на то, что проституция - прямое следствие несправедливого буржуазного строя. Далее советский кинематограф не раз обращался к экранизациям французской литературной классики, и при этом в большинстве случаев образы французских персонажей выглядели положительными - симпатичными, смелыми, отважными и остроумными («Дети капитана Гранта», «Пятнадцатилетний капитан», «Капитан Немо», «Красное и черное», «Д'Артаньян и три мушкетера», «Капитан Фракасс», «Проделки Скапена», «Капитан «Пилигрима», «В поисках капитана Гранта», «Узник замка Иф», «Руанская дева по прозвищу Пышка», «Сирано де Бержерак», «Спаси и сохрани» и др.).

В годы второй мировой войны французская тема в советском кино, конечно, оказалась маргинальной, однако, даже в одном из фильмов о партизанах («Славный малый», 1942) нашлось место для любовной линии французского летчика и деревенской девушки. Фильм, правда, был сочтен цензурой легкомысленным и вышел на экраны лишь в конце 1950-х.

Смелые французские летчики были показаны и других советских фильмах о войне («Беспокойное хозяйство», «Нормандия-Неман»). Героика французского движения сопротивления предстала на экране в фильмах «Убийство на улице Данте» (1956), «Далеко на Западе» (1968) и «Узники Бомона» (1970). Притягательный образ французской медсестры, гибнущей в бою с нацистами, был создан в «Ноктюрне» (1966).

Эпоха «оттепели» внесла свежее дыхание в советские фильмы с «французским акцентом». В лирической комедии «Леон Гаррос ищет друга» (1960) французские персонажи, путешествующие по просторам СССР, выглядели обаятельно и дружелюбно. В «Зеленом огоньке» (1964) очаровательная француженка Николь напевала в московском такси культовую песню из знаменитого фильма «Черный Орфей» (1959) М. Камю. Кстати, несмотря главный приз Каннского фестиваля и «Оскар», «Черный Орфей» так и не добрался до советских экранов, так как, по мнению цензоров из ЦК КПСС, «в этой картине негры изображены по сути дела с колонизаторских позиций, как примитивные «Дети природы», находящиеся во власти слепых биологических инстинктов и религиозного экстаза» (Идеологические комиссии, 1998: 265).

Даже мэтр соцреализма в кино С. Герасимов в те годы не устоял от соблазна «франкофонии»: в одном из эпизодов «Журналиста» (1967) знаменитая французская актриса Анни Жирардо блестяще сыграла роль... самой себя (гораздо позже, уже в эпоху перестройки, она замечательно солировала в драме В. Ахадова «Руфь»).

И хотя «холодная война» время от времени давала о себе знать, линия позитивного изображения Франции и французов на советских экранах продолжилась и после окончания оттепели. Трогательный образ юной француженки, влюбившейся в русского офицерадекабриста, покорил сердца советских зрителей в «Звезде пленительного счастья» (1975) В. Мотыля. Не менее ярким был образ французской красавицы и в шпионском триллере «Тегеран-43» (1980). Одна из самых обворожительных француженок появилась в фильме С. Юткевича «Ленин в Париже» (1981), и это, вероятно, был самый позитивный в советском кино франкофонный женский персонаж. Впрочем, удивляться не приходится - французская звезда Клод Жад («Украденные поцелуи», «Семейный очаг» Ф. Трюффо) талантливо сыграла здесь лучшую подругу В.И. Ленина - Инессу Арманд...

В 1970-1980-х годах жизнерадостные французы и француженки часто возникали на советских экранах в экранизациях веселых оперетт и водевилей («Под крышами Монмартра», «Соломенная шляпка», «Небесные ласточки», «Бал в Савойе», «Принцесса цирка», «Путешествие мсье Перришона», «Портрет мадемуазель Таржи»).

При всем том советский экран мог показать французов и в ином свете: как коварных империалистов («Заговор послов», 1965; «Игра хамелеона», 1986), пособников нацистов («Убийство на улице Данте», 1956), лощенных великосветских негодяев («Разбудите Мухина», 1967; «Последняя дорога», 1986), корыстных убийц («Парижская драма», 1983) и ростовщиков («Гобсек», 1936; 1987).

Но в целом строчка из песни - «я волнуюсь, заслышав французскую речь» - была ключевой в советском киновосприятии Франции и французов. Отсюда нет ничего 
удивительного, что эта линия симпатии продолжилась в российском кино постсоветского периода. К примеру, в экранизациях французской классики («Мушкетёры двадцать лет спустя», «Тайна королевы Анны, или Мушкетёры тридцать лет спустя», «Три мушкетера», «Тартюф», «Простодушный», «Королева Марго», «Графиня де Монсоро» и «Тартарен из Тараскона»). Французы эпохи наполеоновских войн снова возникли в фильмах «1812: Уланская баллада», «Ржевский против Наполеона» и «Василиса». Как и в советские киногоды, герои французского сопротивления влюблялись в русских девушек («Французский вальс»), а французские летчики вместе с русскими громили нацистские эскадрильи («Истребители. Последний бой»). Не был забыт и коварный Дантес, знакомый советским кинозрителям еще по советским фильмам «Разбудите Мухина» и «Последняя дорога»: он снова стрелял в великого русского поэта в драме Натальи Бондарчук «Пушкин: последняя дуэль» (2006).

И все же постсоветские времена принесли во французскую тематику на экране и новые сюжетные линии, которые невозможно было себе представить в эпоху социализма.

Во-первых, на фоне бедственного быта россиян отчетливо проявилась фабула, связанная с обретением французского спутника жизни и в целом ПМЖ во Франции ради лучшей материальной и прочей доли («Белый король, красная королева», «Невеста из Парижа», «Окно в Париж», «Любовь французская и русская», «Зависть богов», «Лиса Алиса», «Француз», «Француз Сережа», «Прогулка по Парижу», «Продавец игрушек», «Доктор Анна»).

В самом деле, негасимый свет парижских окон по-прежнему притягивал российских кинематографистов. Так, перенеся персонажей своей фантастической комедии «Окно в Париж» (1993) прямо из питерской коммуналки начала 1990-х в центр современного Парижа, Юрий Мамин довольно удачно обыграл существенную разницу между славянским и западным менталитетом. Несчастная француженка, случайно оказавшись чуть ли не в чем мать родила на грязных петербургских задворках, беспомощно пыталась звать на помощь и оказалась абсолютно неспособна освоиться в новой для нее обстановке. Зато наши сограждане, открыв волшебное окно на французскую сторону, уже через пару дней бойко торговали на рынке и воровали всё, что «плохо лежит» и т.п. Пожалуй, лучшим анекдотом фильма, достигшим верхней ноты безжалостного сарказма, стала история о неком ресторанном музыканте, по-видимому, «свалившем» во Францию еще в советские времена. Лениво угощая бывшего приятеля, он ругал французов и их обычаи, чувствительно вспоминал Россию и чуть не плакал, когда говорил, что всё, дескать, отдал бы за возможность хоть на миг вернуться в Питер. Ради шутки это желание исполнилось через «окно в Париж». Но вместо обещанного счастливого экстаза эмигрант, увидев фигуру на броневике перед Финляндским вокзалом, впадал в звериное отчаяние...

В еще одной комедии - «Невеста из Парижа» (1992) - молодая француженка приезжала в Санкт-Петербург, чтобы найти материал для диссертации, но влюблялась в русского адвоката... Фильм был простой, незатейливый, явно не претендовавший на глубокомысленную ироничность. Петербургские улицы начала 1990-х кишели бесконечными митингами, демонстрациями и акциями протеста, а бедняга адвокат измученно-уставшим взглядом наблюдал за оптимистичным энтузиазмом своей французской гостьи, для которой все русские беды казались новым аттракционом в лунапарке. Ей все было в диковинку и интересно - тупые физиономии милиционеров, забирающих ее в участок, отсутствие в кранах горячей и холодной воды и т.д.

Жаль, что на главную роль авторы не захотели (или не смогли по финансовым причинам?) пригласить французскую актрису. Александра Захарова играла временами забавно, однако поверить в то, что ее героиня приехала из Парижа, мог, вероятно, лишь самый неискушенный зритель.

Во-вторых, в постсоветские времена стали возможны сюжеты с критикой социалистических времен и нравов («Дорога в рай», «Восток - Запад», «Зависть богов», «Очарование зла», «Таинственная страсть»).

... 1946 год. Кремль объявляет широковещательную акцию добровольного возвращения на родину русских иммигрантов. Обманутые лживыми посулами, тысячи русских решают вернуться в Россию. Среди них врач Алексей (Олег Меньшиков) с женой 
(Сандрин Боннер) и ребенком. Вскоре они понимают, что совершили роковую ошибку... Да и Франция вовсе не спешит протянуть руку помощи своим бывшим гражданам...

С помощью российских сценаристов, актеров и ассистентов Режи Варнье в драме «Восток-Запад» (1999) удалось создать достоверную атмосферу сталинско-хрущевских времен без привычной в западных постановках «клюквы». О. Меньшиков играет человека, пытающегося путем компромисса с властью помочь своей семье выжить. С. Боннер ведет свою героиню по сложному пути - от наивного непонимания окружающей обстановки $к$ горькому познанию "прелестей" (в том числе и лагерных) советской жизни.

... Лето 1957. Москва. Международный фестиваль молодежи и студентов. Ритмы запретного джаза. Улыбающиеся молодые лица... Виталий Москаленко довольно тщательно воссоздает романтическую атмосферу тех лет, когда страна медленно выползала из ледяного плена сталинизма. Любовная история московского студента и его новой подруги француженки русского происхождения - на этом фоне кажется весьма органичной. Однако «Дорога в рай» (1993) - не ретромелодрама: влюбленные находятся между двух огней. С одной стороны, русского парнишку хотят сделать своим осведомителем гэбисты. А с другой - француженка тоже не промах, так как послана парижскими спецслужбами выведать с помощью своего возлюбленного химические секреты его дядюшки... «Дорога в рай» поставлена с чувством стиля: не претендуя на психологическую глубину и аналитичность, эта любовно-шпионская "story", навеяна ностальгией по "оттепели" конца 1950-х...

... 1983. Замужняя женщина, мать взрослого сына неожиданно и страстно влюбляется во французского журналиста. Ретро Владимира Меньшова отчетливо напоминает по стилю его знаменитый хит - оскароносец «Москва слезам не верит». Та же четкость и ясность рассказанной истории. То же умелое сочетание мелодраматического и комического. Столь же любовно выписанные эпизодические персонажи. Правда, в «Зависти богов» добавлены политические и эротические мотивы. Кто знает, каким бы был фильм, сыграй главную мужскую роль французский актер, но Анатолий Лобоцкий в роли парижского репортера кажется вполне убедительным. Особенно на фоне откровенно ряженого Жерара Депардье в роли ветерана эскадрильи «Нормандия-Неман».

В-третьих, французская тематика российского кино прикоснулась и к криминальным сюжетам («Линия жизни», «Лиса Алиса», «Убойная сила-5», «Виктор»), где современная Россия нередко выглядела как мафиозное государство. Впрочем, такого рода сюжетные повороты в этой теме ни в 1990-х, ни в XXI веке отнюдь не доминировали...

\title{
Кинематографические стереотипъ советских и российских игровъх фильмов, связаннъе с французской тематикой и французскими персонажсами
}

\section{Структура стереотипов фильмов драматического жанра}

\begin{abstract}
исторический период, место действия: любой отрезок времени, СССР/Россия/Франция, другие страны.

обстановка, предметы быта: скромные жилища и предметы быта советских персонажей, комфортабельные жилища и предметы быта французских персонажей и многих персонажей времен Российской империи и постсоветских времен. Впрочем, если действие фильма разворачивается во время войны, то условия жизни как многих персонажей весъма аскетичны.
\end{abstract}

приемъ изображения действительности: в меру реалистичное изображение жизни людей во Франции и Французов в СССР/России.

персонажи, их цуенности, идеи, одежды, телосложение, лексика, мимика, жесты: положительные персонажи - носители революционных / демократических идей (что свойственно в большей степени советскому кино до 196о-х годов, так как в последующие годы французские персонажи часто представили на советском $u$ российском экранах в легкомысленно-опереточном ключе); отрицательные персонажи носители антигуманных идей. Персонажей разделяет не только социальный, но часто и материальный статус. Разделенные идеологией и мировоззрением (буржуазным, 
коммунистическим) персонажи, как правило, поданы согласно установкам источника медиатекста: большинство положительных французских персонажей показаны красивыми, обаятельными, симпатичными и доброжелательными людьми, быть может, порой и легкомысленными, зато веселыми и остроумными.

существенное изменение в жизни персонажей: отрицательные персонажи (это как правило, не французы, а, например, нацисты и их пособники) собираются воплотить в жизнь свои антигуманные планы.

возникиая проблема: жизнь положительных персонажей под угрозой.

поиски решения проблемъ: борьба положительных персонажей с отрицательными.

решение проблемы: уничтожение/арест отрицательных персонажей, возвращение к мирной жизни.

Характернъце примерь фильмов: «Убийство на улице Данте» (1956), «Нормандия-Неман» (196о), «Ноктюрн» (1966), «Далеко на Западе» (1968), «Узники Бомона» (1970), «Тегеран-43» (1980), «Мать Мария» (1982), «Истребители. Последний бой» (2015) и $\partial p$.

\section{Структура стереотипов фильмов мелодраматического жанра}

исторический период, место действия: любой отрезок времени, СССР/Россия/Франция, другие страны.

обстановка, предметы бъта: скромные жилища и предметы быта советских персонажей, комфортабельные жилища и предметы быта французских персонажей $u$ многих персонажей времен Российской империи и постсоветских времен. Впрочем, если действие фильма разворачивается во время войны, то условия жизни как многих персонажей весъма аскетичны.

приемъ изображения действительности: в меру реалистичное изображение жизни людей во Франции и французов в СССР/России (надо отметить, что жанр мелодрамы в большей степени свойственен постсоветскому периоду кинематографа).

персонажи, их ценности, идеи, одеждъ, телосложение, лексика, мимика, жесты: мужской и женский персонажи с контрастным идеологическим и социальным статусом. Персонажи, как правило, обладают стройным телосложением и выглядят симпатично. Их одежда, лексика и мимика находятся в «среднестатистических» рамках.

существенное изменение в жизни персонажей: встреча мужского и женского персонажей.

возникшая проблема: идеологический и социальный мезальянс.

поиски решения проблемы: персонажи преодолевают идеологические $u$ социальные препятствия на пути их любви.

решение проблемъ: свадъба/любовная гармония, или смерть, разлука персонажей.

Характернъе примеръ фильмов: «Дорога в рай» (1993), «Любовь французская и русская» (1994), «Французский вальс» (1994), «Зависть богов» (20оо), «Лиса Алиса» (2001), «Француз» (2003), «Француз Сережа» (2008) и др.

\section{Структура фильмов комедийного жанра}

исторический период, место действия: любой отрезок времени, СССР/Россия/Франция, другие страны.

обстановка, предметы быта: скромные жилища и предметы быта советских персонажей, комфортабельные жилища и предметы быта французских персонажей и многих персонажей времен Российской империи и постсоветских времен. Впрочем, если действие фильма разворачивается во время войны (например, в фильме «Славный малый» (1942), то условия жизни как многих персонажей весъма аскетичны).

приемъ изображсения действительности: как правило, условно-гротескные.

персонажси, их ценности, идеи, одежды, телосложение, лексика, мимика, жесть: мужской и женский персонажи с контрастным идеологическим и социальным 
статусом. Персонажи, как правило, обладают стройным телосложением и выглядят симпатично. Их одежда, лексика и мимика находятся в «среднестатистических» рамках.

существенное изменение в жизни персонажей: персонажи встречаются при забавньх/эксцентрических обстоятельствах, при этом французские персонажи часто находятся на территории СССР или России.

возникшая проблема: «культурный шок», взаимное непонимание.

поиски решения проблемъ: в серии смешных/эксцентрических ситуаций персонажи преодолевают препятствия на пути взаимопонимания.

решение проблемы: гармония взаимопонимания персонажей, окрашенная юмором.

Характерные примеры фильмов: «Леон Гаррос ищет друга» (1960), «Невеста из Парижа» (1992), «Окно в Париж» (1993), «Тысяча и один рецепт влюбленного кулинара» (1996), «Парижане» (2006) и др.

\section{Структура стереотипов фильмов жанра триллера или детектива}

исторический период, место действия: любой отрезок времени, СССР/Россия/Франция, другие страны.

обстановка, предметы бътта: скромные жилища и предметы быта советских персонажей, комфортабельные жилища и предметы быта французских персонажей и многих персонажей времен Российской империи и постсоветских времен. Однако, находясь на территории чужой страны, шпионы приспосабливаются к любым жилищным $u$ бытовым условиям.

приемъ изображения действительности: довольно реалистичное изображение жизни людей.

персонажи, их ценности, идеи, одежды, телосложение, лексика, мимика, жесты: положительные (пограничники, сотрудники контрразведки, ипионы, мирные граждане СССР/России) и отрицательные (те же лица, но уже иностранные граждане, включая французов). Разделенные идеологией и мировоззрением (буржуазным, коммунистическим) персонажи, как правило, обладают крепким телосложением $u$ выглядят согласно установкам источника медиатекста, лексика, мимика, тембр голоса и внешность персонажей построены под их текущие детективно-ипионские задачи.

существенное изменение в жизни персонажей: отрицательные персонажи совершают преступление (нелегальный переход границы, диверсия, шпионаж, шантаж, кража государственных секретов, убийства).

возникшая проблема: нарушение закона.

поиски решения проблемы: расследование преступления, преследование отрицательных персонажей.

решение проблемы: положительные персонажи разоблачают /ловят /уничтожают отрицательных.

Характернье примерь фильмов: «Французский ипион» (2013), "Душа шпиона» (2014) и др.

Наш анализ советских и российских игровых фильмов, связанных с французской тематикой и французскими персонажами, позволил нам составить таблицу 1. 
Таблица 1. Советские и российские игровые фильмы, связанные с французской тематикой и французскими персонажами

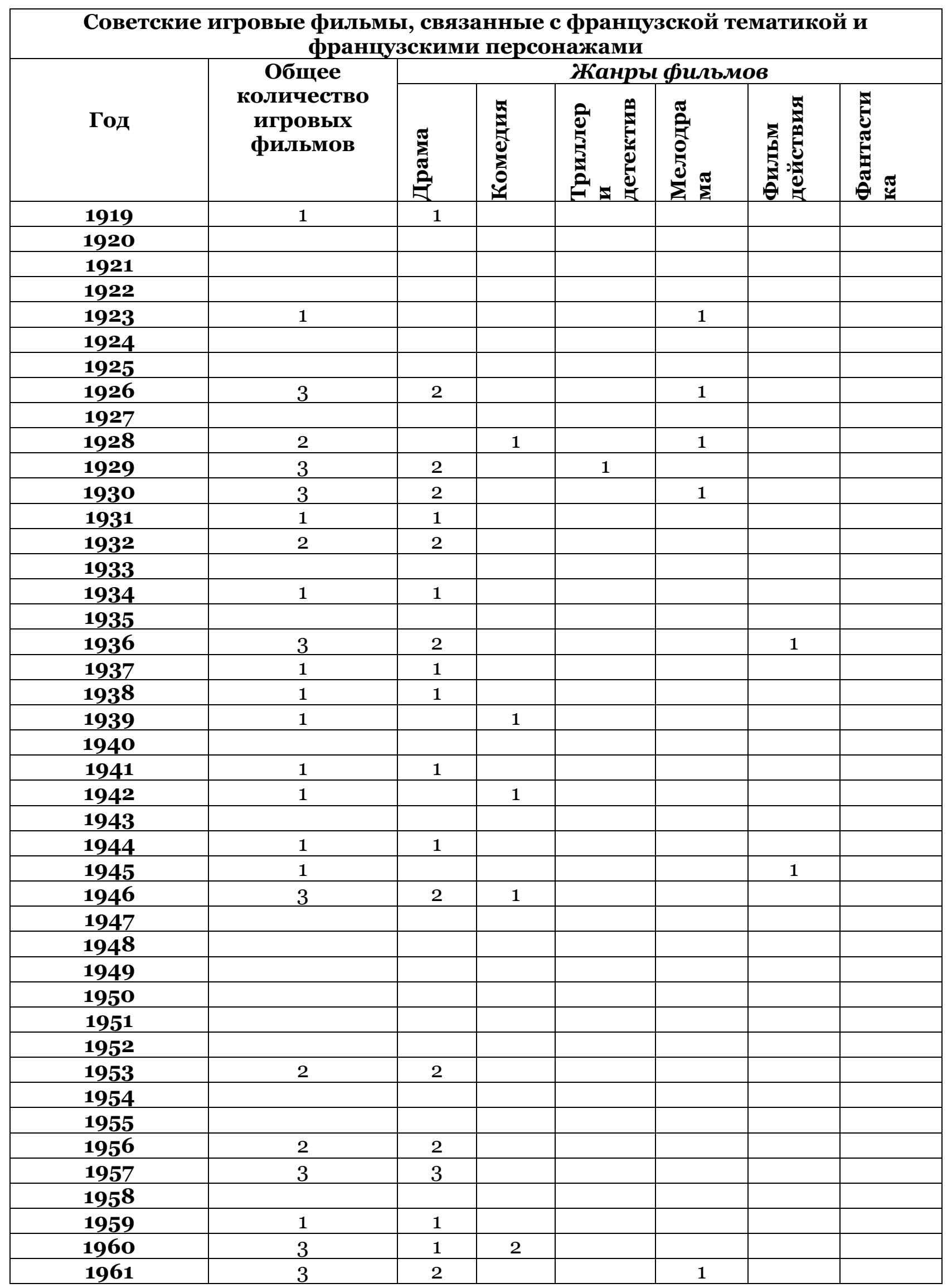




\begin{tabular}{|c|c|c|c|c|c|c|c|}
\hline 1962 & 1 & & 1 & & & & \\
\hline \multicolumn{8}{|l|}{1963} \\
\hline 1964 & 2 & 2 & & & & & \\
\hline 1965 & 5 & 3 & & 1 & & & 1 \\
\hline 1966 & 1 & 1 & & & & & \\
\hline 1967 & 2 & 1 & 1 & & & & \\
\hline 1968 & 4 & 1 & 1 & & 1 & 1 & \\
\hline 1969 & 2 & 1 & & & 1 & & \\
\hline 1970 & 1 & 1 & & & & & \\
\hline 1971 & 3 & 2 & 1 & & & & \\
\hline 1972 & 1 & 1 & & & & & \\
\hline 1973 & 2 & 1 & & 1 & & & \\
\hline 1974 & 2 & 1 & 1 & & & & \\
\hline 1975 & 6 & 4 & 1 & & & & 1 \\
\hline 1976 & 4 & 1 & 2 & & 1 & & \\
\hline 1977 & 1 & 1 & & & & & \\
\hline 1978 & 4 & 2 & 1 & & 1 & & \\
\hline 1979 & 3 & & 2 & & 1 & & \\
\hline 1980 & 7 & 2 & 1 & 2 & 1 & 1 & \\
\hline 1981 & 2 & 1 & 1 & & & & \\
\hline 1982 & 4 & 2 & & 1 & 1 & & \\
\hline 1983 & 2 & 1 & 1 & & & & \\
\hline 1984 & 5 & 4 & & & 1 & & \\
\hline 1985 & 4 & 2 & 1 & & & 1 & \\
\hline 1986 & 4 & 1 & 2 & & & 1 & \\
\hline 1987 & 3 & 2 & & & 1 & & \\
\hline 1988 & 1 & 1 & & & & & \\
\hline 1989 & 4 & 4 & & & & & \\
\hline 1990 & 2 & 1 & 1 & & & & \\
\hline 1991 & 2 & 1 & 1 & & & & \\
\hline $\begin{array}{c}\text { Всего } \\
\text { (советский } \\
\text { период) }\end{array}$ & 128 & 75 & 25 & 6 & 14 & 6 & 2 \\
\hline \multicolumn{8}{|c|}{$\begin{array}{c}\text { Российские игровые фильмы, связанные с французской тематикой и } \\
\text { французскии персонажами }\end{array}$} \\
\hline \multirow[b]{2}{*}{ Год } & \multirow{2}{*}{$\begin{array}{c}\text { Общее } \\
\text { количество } \\
\text { игровых } \\
\text { фильмов }\end{array}$} & \multicolumn{6}{|c|}{ Жанры фильмов } \\
\hline & & 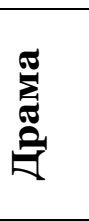 & 至 & 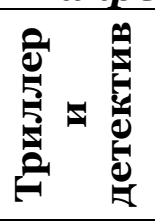 & 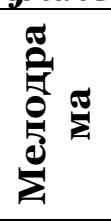 & 焉 & ש্ \\
\hline 1992 & 4 & 2 & 2 & & & & \\
\hline 1993 & 5 & 2 & 1 & & 2 & & \\
\hline 1994 & 3 & & 1 & & 2 & & \\
\hline 1995 & 1 & 1 & & & & & \\
\hline 1996 & 3 & 1 & 2 & & & & \\
\hline 1997 & 1 & 1 & & & & & \\
\hline \multicolumn{8}{|l|}{1998} \\
\hline 1999 & 1 & 1 & & & & & \\
\hline 2000 & 2 & 1 & & & 1 & & \\
\hline 2001 & 3 & & 1 & 1 & 1 & & \\
\hline 2002 & 1 & & & 1 & & & \\
\hline 2003 & 4 & 1 & 1 & 1 & 1 & & \\
\hline
\end{tabular}




\begin{tabular}{|c|c|c|c|c|c|c|c|}
\hline $\mathbf{2 0 0 4}$ & 1 & & & & 1 & & \\
\hline 2005 & 2 & & & 1 & 1 & & \\
\hline 2006 & 3 & 2 & 1 & & & & \\
\hline 2007 & 1 & & 1 & & & & \\
\hline 2008 & 4 & & 1 & & 3 & & \\
\hline 2009 & 3 & 1 & 1 & 1 & & & \\
\hline 2010 & 3 & 1 & & 1 & 1 & & \\
\hline $\mathbf{2 0 1 1}$ & 4 & 2 & 1 & & 1 & & \\
\hline 2012 & 5 & 1 & 3 & & & 1 & \\
\hline $\mathbf{2 0 1 3}$ & 4 & 1 & 1 & 1 & & 1 & \\
\hline $\mathbf{2 0 1 4}$ & 6 & 1 & 2 & 1 & 2 & & \\
\hline $\mathbf{2 0 1 5}$ & 4 & 3 & & & 1 & & \\
\hline $\mathbf{2 0 1 6}$ & 7 & 2 & 2 & 1 & 2 & & \\
\hline $\mathbf{2 0 1 7}$ & 3 & 1 & & 1 & 1 & & \\
\hline $\begin{array}{c}\text { Всего } \\
\text { (россииский }\end{array}$ & $\mathbf{7 8}$ & $\mathbf{2 5}$ & $\mathbf{2 1}$ & $\mathbf{1 0}$ & $\mathbf{2 0}$ & $\mathbf{2}$ & $\mathbf{0}$ \\
\hline период) & & & & & & & \\
\hline ВСЕГО: & $\mathbf{2 0 6}$ & $\mathbf{1 0 0}$ & $\mathbf{4 6}$ & $\mathbf{1 6}$ & $\mathbf{3 4}$ & $\mathbf{8}$ & $\mathbf{2}$ \\
\hline
\end{tabular}

\section{5. Выводы}

Итак, с 1919 по 2018 годы было снято 206 советских и российских игровых фильмов, связанных с Францией и французскими персонажами. Из них два десятка - копродукция с Францией и другими странами, а тридцать - экранизации французской литературной классики (Ги де Мопассана, Ж. Верна, В. Гюго, А. Дюма, Стендаля, Вольтера, Ж.-Б. Мольера, Т. Готье, О. де Бальзака, Э. Ростана, Г. Флобера, А. Доде, Ж.-П. Сартра и др.).

Что касается жанрового спектра этих фильмов, то здесь очевидна доминанта жанра драмы (сто фильмов). Далее следуют (в порядке убывания): комедии (46 фильмов), мелодрамы (34 фильма), детективы и триллеры (16 фильмов), фильмы действия (8) и фантастические фильмы (2).

Из 206 фильмов, связанных с французскими персонажами, 142 рассказывают о временном периоде XX-XXI веков. В этих фильмах доминирует следующие темы: дружба и любовные отношения между русскими и французскими персонажами, что нередко связано с совместной борьбой с нацистами в годы второй мировой войны (32 фильма), жизнь французских персонажей, попавших в СССР или Россию (23 фильма, решенные в жанрах комедии, мелодрамы и драмы), эмиграция русских персонажей во Францию (19 фильмов), шпионаж (6 фильмов).

Анализируя цифровые данные, можно отметить существенный рост (примерно вдвое) внимания российских кинематографистов к французской тематике теме в постсоветское время. Так за советские годы было поставлено 128 фильмов с французскими персонажами, тогда как за 26 последних года (1992-2018) таких фильмов снято уже 78. При сохранении доминанты драмы (75 драм в советский период и 25 - в постсоветский) отчетливо наблюдается повышение доли фильмов мелодраматического жанра (с 14 в советский период до 20 - в постсоветский).

Следовательно, интерес к французской тематике в советском и российском кино неслучаен, что и понятно - история России и Франции тесно связана, и это не только история войн, но и дружбы, взаимного притяжения культур.

\section{6. Благодарности}

Данная статья написана при финансовой поддержке государственной стипендии Министерства культуры Российской Федерации (2018).

\section{Литература}

Баскаков, 1981 - Баскаков В.Е. Противоборство идей на западном экране // Западный кинематограф: проблемы и тенденции. М.: Знание, 1981. С. 3-20. 
Волкогонов, 1983 - Волкогонов Д.А. Психологическая война. М.: Воениздат, 1983. 288 с.

Гудков, 2005 - Гудков Л. Идеологема «врага»: «враги» как массовый синдром и механизм социокультурной интеграции // Образ врага / Сост. Л. Гудков. М., 2005.

Зоркая, 2005 - Зоркая Н.М. История советского кино. СПб.: Алетейя, 2005.

Идеологические комиссии ЦК КПСС 1958 - Идеологические комиссии ЦК КПСС 19581964. M., 1998. С. 265.

Климонтович, 1990 - Климонтович Н. Они как шпионы // Искусство кино. 1990. № 11.

Колесникова, 2007 - Колесникова А.Г. Образ врага периода холодной войны в советском игровом кино 1960 - 1970-х годов // Российская история. 2007. № 5. С. 162-168.

Колесникова, 2008 - Колесникова А.Г. Рыцари эпохи «холодной войны» (образ врага в советских приключенческих фильмах 1960-1970-х гг. // Клио. 2008. № 3. С.144-149.

Колесникова, 2010 - Колесникова А.Г. Формирование и эволюция образа врага периода «холодной войны» в советском кинематографе (середина 1950-х - середина 1980-х гг.). Дис. ... канд. ист. наук. М., 2010.

Лотман, 1973 - Лотман Ю.М. Семиотика кино и проблемы киноэстетики. Таллин, 1973.

Наринский, 2006 - Наринский M.M. Происхождение холодной войны // От Фултона до Мальты: как началась и закончилась холодная война. Горбачевские чтения. Вып. 4. / Ред. О.М. Здравомыслова. М.: Горбачев-Фонд, 2006. С.161-171.

Невежин, 1999 - Невежин В.А. Советская пропаганда и идеологическая подготовка к войне (вторая половина 1930-х - начало 1940-х гг.). Дис. ... д-ра. ист. наук. М., 1999.

Немкина, 2005 - Немкина Л.Н. Советская пропаганда периода «холодной войны»: методология и эффективная технология // Acta Diurna. 2005. № 3. URL: http://psujourn.narod.ru/vestnik/vyp_3/ne_cold.html

Рукавишников, 2000 - Рукавишников B.О. Холодная война, холодный мир. М.: Академический проект, 2000. 864 с.

Стишова, Сиривля, 2003 - Стишова E., Сиривля Н. Соловьи на 17-й улице [Материалы дискуссии об антиамериканизме в советском кинематографе, Pittsburg University, май 2003] // Искусство кино. 2003. № 10. С.5-21.

Туровская, 1996 - Туровская М.И. Фильмы «холодной войны» // Искусство кино. 1996. № 9. C.98-106.

Туровская, 2003 - Туровская М.И. Blow up, или Герои безгеройного времени - 2. М.: МИК, 2003. $288 \mathrm{c.}$

Уткин, 2005 - Уткин А. Мировая «холодная война». М.: Алгоритм, Эксмо, 2005.

Фатеев, 1999 - Фатеев А.В. Образ врага в советской пропаганде, 1945-1954. М.: Изд-во PAH, 1999.

Шенин, 2003 - Шенин С.Ю. История холодной войны. Саратов: Изд-во Саратов. гос. ун-та 2003. $32 \mathrm{c}$.

Эко, 1998 - Эко У. Отсутствующая структура. Введение в семиологию. СПб.: Петрополис, 1998. 432 с.

Britton, 2006 - Britton, $W$. Onscreen and Undercover. The Ultimate Book of Movie Espionage. Westport-London: Praeger, 2006, 209 p.

Dubois, 2007 - Dubois, $R$. Une histoire politique du cinema. Paris: Sulliver, 2007, 216 p.

Eco, $1976-E c o, U$. A Theory of Semiotics. Bloomington: Indiana University Press, 1976.

Fried, 1998 - Fried, R.M. The Russian are coming! The Russian are coming! N.Y., Oxford: Oxford University Press, 1998, 220 p.

Haynes, 1966 - Haynes, J.E. Red Scare or Red Menace? Chicago: I.R. Dee, 1966, 214 p.

Keen, 1986 - Keen, S. Faces of the Enemy. San Francisco: Harper and Row, 1986.

Kenez, 1992 - Kenez, P. Cinema and Soviet Society, 1917-1953. Cambridge, N.Y.: Cambridge University Press, 1992, 281 p.

Lacourbe, 1985 - Lacourbe, $R$. La Guerre froide dans le cinema d'espionnage. Paris: Henri Veyrier, 1985, $315 \mathrm{p}$.

LaFeber, 1990 - LaFeber, W. America, Russia and Cold War. New York: Alfred A. Knopf, 1990.

Lauren, 2000 - Lauren, $N$. L'Oeil du Kremlin. Cinema et censure en URSS sous Stalin (19281953). Toulouse: Privat, 2000, 286 p. 
Lawton, 2004 - Lawton, A. Imaging Russia 2000. Films and Facts. Washington, DC: New Academia Publishing, 2004, 348 p.

Levering, 1982 - Levering, R. B. The Cold War, 1945-1972. Arlington Heights: Harlan Davidson, 1982.

Potter, 2001 - Potter, W.J. Media Literacy. Thousand Oaks - London: Sage Publication, 2001, 423 p.

Reid, 2006 - Reid, J.H. Great Cinema Detectives. L.A.: Hollywood Classics 21, 2006, 264 p.

Robin, 2001 - Robin, R.T. The Making of the Cold War Enemy. Princeton, Oxford: Princeton University Press, 2001, $277 \mathrm{p}$.

Rubenstein, 1979 - Rubenstein, L. The Great Spy Films. Secaucus, N.J.: The Citadel Press, 1979, 223 p.

Shaw, 2006 - Shaw, T. British Cinema and the Cold War. N.Y.: I.B. Tauris, 2006, 280 p.

Shaw, Youngblood, 2010 - Shaw, T., Youngblood, D.J. Cinematic Cold War: The American and Soviet Struggle for Heart and Minds. Lawrence: University Press of Kansas, 2010, 301 p.

Shlapentokh, 1993 - Shlapentokh D. and V. Soviet Cinematography 1918-1991: Ideological Conflict and Social Reality. N.Y.: Aldine de Gruyter, 1993.

Silverblatt, 2001 - Silverblatt, A. Media Literacy. Westport, Connecticut - London: Praeger, 2001, 449 p.

Small, 1980 - Small, M. Hollywood and Teaching About Russian-American Relations. Film and History, N 10, 1980, pp. 1-8.

Strada, 1989 - Strada, M. A Half Century of American Cinematic Imagery: Hollywood's Portrayal of Russian Characters, 1933-1988. Coexistence, N 26, 1989, pp. 333-350.

Strada, Troper, 1997 - Strada, M.J., Troper, H.R. Friend or Foe? Russian in American Film and Foreign Policy. Lanham, Md., \& London: The Scarecrow Press, 1997, 255 p.

Turovskaya, 1993 - Turovskaya, M. Soviet Films of the Cold War. In: Taylor, R. and Spring, D. (Eds.). Stalinism and Soviet Cinema. London and New York: Routledge, 1993, pp. 131-141.

Westad, 2007 - Westad, O.A. The Global Cold War. Cambridge: University Press, 2007, 484 p.

Whitfield, 1991 - Whitfield, S.J. The Culture of the Cold War. Baltimore: John Hopkins University Press, 1991.

\section{References}

Baskakov, 1981 - Baskakov V.E. (1981). Protivoborstvo idei na zapadnom ekrane [Controversy of ideas on the western screen. Western cinema: problems and trends]. Zapadnyi kinematograf: problemy i tendentsii. M.: Znanie, pp. 3-20.

Eko, 1998 - Eko U. (1998). Otsutstvuyushchaya struktura [The missing structure]. Vvedenie v semiologiyu. SPb.: Petropolis, 432 p.

Fateev, 1999 - Fateev A.V. (1999). Obraz vraga v sovetskoi propagande, 1945-1954 [The image of the enemy in Soviet propaganda, 1945-1954]. M.: Izd-vo RAN.

Gudkov, 2005 - Gudkov L. (2005). Ideologema «vraga»: "vragi» kak massovyi sindrom i mekhanizm sotsiokul'turnoi integratsii [Ideologem "enemy": "enemies" as a mass syndrome and the mechanism of socio-cultural integration]. Obraz vraga. Sost. L. Gudkov. M.

Ideologicheskie komissii TsK KPSS 1958 - Ideologicheskie komissii TsK KPSS 1958-1964 [Ideological commissions of the Central Committee of Soviet Communist Party, 1958-1964]. M., P. 265.

Klimontovich, 1990 - Klimontovich N. (1990). Oni kak shpiony [They are like spies]. Iskusstvo kino. № 11.

Kolesnikova, 2007 - Kolesnikova A.G. (2007). Obraz vraga perioda kholodnoi voiny v sovetskom igrovom kino 1960 - 1970-kh godov [The image of the enemy of the period of the Cold War in Soviet feature films of the 1960s-1970s]. Rossiiskaya istoriya. № 5. pp. 162-168.

Kolesnikova, 2008 - Kolesnikova A.G. (2008). Rytsari epokhi «kholodnoi voiny» (obraz vraga v sovetskikh priklyuchencheskikh fil'makh 1960-1970-kh gg. [Knights of the cold war era (the enemy's image in soviet adventure films of the 1960s-1970s]. Klio. № 3. pp. 144-149.

Kolesnikova, 2010 - Kolesnikova A.G. (2010). Formirovanie i evolyutsiya obraza vraga perioda «kholodnoi voiny» v sovetskom kinematografe (seredina 1950-kh - seredina 1980-kh gg.) [The image of the enemy of the period of the Cold War in Soviet feature films of the 1960s - 1970s]. Dis. ... kand. ist. nauk. M. 
Lotman, 1973 - Lotman Yu.M. (1973). Semiotika kino i problemy kinoestetiki [Semiotics of cinema and problems of cinema aesthetics.]. Tallin.

Narinskii, 2006 - Narinskii M.M. (2006). Proiskhozhdenie kholodnoi voiny. Ot Fultona do Mal'ty: kak nachalas' i zakonchilas' kholodnaya voina [The origin of the cold war. From Fulton to Malta: how the cold war began and ended]. Gorbachevskie chteniya. Vyp. 4. Red. O.M. Zdravomyslova. M.: Gorbachev-Fond, pp. 161-171.

Nemkina, 2005 - Nemkina L.N. (2005). Sovetskaya propaganda perioda «kholodnoi voiny»: metodologiya i effektivnaya tekhnologiya [Soviet propaganda of the Cold War period: methodology and effective technology]. Acta Diurna. № 3. URL: http://psujourn.narod.ru/vestnik/ vyp_3/ ne_cold.html

Nevezhin, 1999 - Nevezhin V.A. (1999). Sovetskaya propaganda i ideologicheskaya podgotovka $\mathrm{k}$ voine (vtoraya polovina 1930-kh - nachalo 1940-kh gg.) [Soviet propaganda and ideological preparation for war (second half of the 1930 - early 1940's)]. Dis. ... d-ra. ist. nauk. M.

Rukavishnikov, 2000 - Rukavishnikov V.O. (2000). Kholodnaya voina, kholodnyi mir [Cold war, cold world.]. M.: Akademicheskii proekt, 864 p.

Shenin, 2003 - Shenin S.Yu. (2003). Istoriya kholodnoi voiny [History of the Cold War]. Saratov: Izd-vo Saratov. gos. un-ta, $32 \mathrm{p}$.

Stishova, Sirivlya, 2003 - Stishova E., Sirivlya N. (2003). Solov'i na 17-i ulitse [Nightingales on 17th Street]. Materialy diskussii ob antiamerikanizme v sovetskom kinematografe, Pittsburg University, mai 2003. Iskusstvo kino. № 10. pp. 5-21.

Turovskaya, 1996 - Turovskaya M.I. (1996). Fil'my «kholodnoi voiny» [Films of the cold war]. Iskusstvo kino. № 9. pp. 98-106.

Turovskaya, 2003 - Turovskaya M.I. (2003). Blow up, ili Geroi bezgeroinogo vremeni - 2 [Blow up, or Heroes of Time-Free Time - 2.]. M.: MIK,288 p.

Utkin, 2005 - Utkin A. (2005). Mirovaya «kholodnaya voina» [World of "cold war".]. M.: Algoritm, Eksmo.

Volkogonov, 1983 - Volkogonov D.A. (1983). Psikhologicheskaya voina [Psychological war]. M.: Voenizdat, 288 p.

Zorkaya, 2005 - Zorkaya N.M. (2005). Istoriya sovetskogo kino [The history of Soviet cinema]. SPb.: Aleteiya.

Britton, 2006 - Britton, $W$. (2006). Onscreen and Undercover. The Ultimate Book of Movie Espionage. Westport-London: Praeger, $209 \mathrm{p}$.

Dubois, 2007 - Dubois, R. (2007). Une histoire politique du cinema. Paris: Sulliver, 216 p.

Eco, 1976 - Eco, $U$. (1976). A Theory of Semiotics. Bloomington: Indiana University Press.

Fried, 1998 - Fried, R.M. (1998). The Russian are coming! The Russian are coming! N.Y., Oxford: Oxford University Press, 220 p.

Haynes, 1966 - Haynes, J.E. (1966). Red Scare or Red Menace? Chicago: I.R.Dee, 214 p.

Keen, 1986 - Keen, S. (1986). Faces of the Enemy. San Francisco: Harper and Row.

Kenez, 1992 - Kenez, P. (1992). Cinema and Soviet Society, 1917-1953. Cambridge, N.Y.: Cambridge University Press, $281 \mathrm{p}$.

Lacourbe, 1985 - Lacourbe, $R$. (1985). La Guerre froide dans le cinema d'espionnage. Paris: Henri Veyrier, $315 \mathrm{p}$. Knopf.

LaFeber, 1990 - LaFeber, W. (1990). America, Russia and Cold War. New York: Alfred A.

Lauren, 2000 - Lauren, N. (2000). L'Oeil du Kremlin. Cinema et censure en URSS sous Stalin (1928-1953). Toulouse: Privat, 286 p.

Lawton, 2004 - Lawton, A. (2004). Imaging Russia 2000. Films and Facts. Washington, DC: New Academia Publishing, 348 p.

Davidson.

Levering, 1982 - Levering, R.B. (1982). The Cold War, 1945-1972. Arlington Heights: Harlan

Potter, 2001 - Potter, W.J. (2001). Media Literacy. Thousand Oaks - London: Sage

Publication, $423 \mathrm{p}$.

Reid, 2006 - Reid, J.H. (2006). Great Cinema Detectives. L.A.: Hollywood Classics 21, 264 p.

Robin, 2001 - Robin, R.T. (2001). The Making of the Cold War Enemy. Princeton, Oxford:

Princeton University Press, 277 p. 
Rubenstein, 1979 - Rubenstein, L. (1979). The Great Spy Films. Secaucus, N.J.: The Citadel Press, $223 \mathrm{p}$.

Shaw, Youngblood, 2010 - Shaw, T., Youngblood, D.J. (2010). Cinematic Cold War: The American and Soviet Struggle for Heart and Minds. Lawrence: University Press of Kansas, $301 \mathrm{p}$.

Shaw, 2006 - Shaw, T. (2006). British Cinema and the Cold War. N.Y.: I.B. Tauris, 280 p.

Shlapentokh, 1993 - Shlapentokh D. and V. (1993). Soviet Cinematography 1918-1991: Ideological Conflict and Social Reality. N.Y.: Aldine de Gruyter.

Silverblatt, 2001 - Silverblatt, A. (2001). Media Literacy. Westport, Connecticut - London: Praeger, $449 \mathrm{p}$.

Small, 1980 - Small, M. (1980). Hollywood and Teaching About Russian-American Relations. Film and History, N 10, pp. 1-8.

Strada, Troper, 1997 - Strada, M.J., Troper, H.R. (1997). Friend or Foe?: Russian in American Film and Foreign Policy. Lanham, Md., \& London: The Scarecrow Press, 255 p.

Strada, 1989 - Strada, M. (1989). A Half Century of American Cinematic Imagery: Hollywood's Portrayal of Russian Characters, 1933-1988. Coexistence, N 26, pp. 333-350.

Turovskaya, 1993 - Turovskaya, M. (1993). Soviet Films of the Cold War. In: Taylor, R. and Spring, D. (Eds.). Stalinism and Soviet Cinema. London and New York: Routledge, pp. 131-141.

Westad, 2007 - Westad, O.A. (2007). The Global Cold War. Cambridge: University Press, $484 \mathrm{p}$.

Whitfield, 1991 - Whitfield, S.J. (1991). The Culture of the Cold War. Baltimore: John Hopkins University Press.

\section{Образ Франции и французов на советском и российском экранах}

Александр Федоров а , *

a Ростовский государственный экономический университет, Российская Федерация

Аннотация. Объект исследования - процесс развития темы образа Франции и французов на советском и российском экранах. Предмет исследования - эволюция основных идеологических концепций и кинематографических стереотипов темы образа Франции и французов на советском и российском экранах.

Задачи исследования: определить место и роль темы образа Франции и французов отечественном игровом кинематографе; изучить кинематографический, политический, идеологический, социокультурный, контекст, основные этапы развития заявленной в проекте темы, направления, цели, задачи, авторские концепции трактовки данной темы на советском и российском экранах; осуществить классификацию и сравнительный анализ идеологии, моделей содержания, модификаций жанра, стереотипов отечественного кинематографа, связанного с трактовками образа Франции и французов.

Что касается статистических данных, то можно отметить существенный рост (примерно вдвое) внимания российских кинематографистов к французской тематике теме в постсоветское время. Так за советские годы было поставлено 128 фильма с французскими персонажами, тогда как за 26 последних года (1992-2018) таких фильмов снято уже 78. При сохранении доминанты драмы (75 драм в советский период и 25 - в постсоветский) отчетливо наблюдается повышение доли фильмов мелодраматического жанра (с 14 в советский период до 20 - в постсоветский).

Следовательно, интерес к французской тематике в советском и российском кино неслучаен, что и понятно - история России и Франции тесно связана, и это не только история войн, но и дружбы, взаимного притяжения культур.

Ключевые слова: Франция, французы, СССР, Россия, экран, кинематограф, фильм, холодная война, конфронтация, медиакультура, медиатекст.

*Корреспондирующий автор

Адреса электронной почты: 1954alex@mail.ru (А. Федоров) 


\section{Французы в советском и российском кино}

(Фильмография игровых фильмов без учета фильмов в жанре сказки)

1.

Французы в советском кино (1919-1991)

1919

Пролетарии всех стран, соединяйтесь! Россия, 1919. Режиссер Б. Сушкевич. Сценарист В. Добровольский. Актеры: Б. Сушкевич и др. Драма.

1923

Помещик. СССР, 1923. Режиссеры: В. Гардин, О. Преображенская. Актеры: И.Таланов, Б. Чуевский, И. Капралов и др. Мелодрама.

1926

Декабристы. СССР, 1926. Режиссер А. Ивановский. Сценаристы: А. Ивановский, П. Щёголев. Актеры: В. Максимов, Е. Боронихин, В.Анненкова, Б. Тамарин и др. Драма.

П.К.П. (Пилсудский купил Петлюру). СССР, 1926. Режиссеры: А. Лундин, Г. Стабовой. Сценаристы: Г. Стабовой, Я. Лифшиц. Актеры: Н. Кучинский, М. Ляров, Ю.Тютюнник и др. Драма.

Преступление княжны Ширванской. СССР, 1926. Режиссер и сценарист И. Перестиани. Актеры: М. Ширай, П. Есиковский, С. Жозеффи-Вахнянская и др. Мелодрама.

1928

Ася. СССР, 1928. Режиссер А. Ивановский. Сценаристы: М. Блейман, Ю.Тынянов, Ю. Оксман. Актеры: О. Розевская (Богоявленская), К. Хохлов, Н. Скарская и др. Мелодрама.

Октябрюхов и Декабрюхов. СССР, 1928. Режиссеры: А. Смирнов, А. Смирнова (Искандер). Сценарист В. Маяковский. Актеры: Д. Васильчиков, М. Цибульский, М. Егорова, В. Корш-Саблин, А. Симонов и др. Комедия.

1929

Веселая канарейка. СССР, 1929. Режиссер Л.Кулешов. Сценаристы: А. Мариенгоф, Б. Гусман. Актеры: Г. Кравченко, А. Файт, А. Войцик, С.Комаров, В.Пудовкин и др. Детектив.

Новый Вавилон. СССР, 1929. Режиссеры: Г. Козинцев, Л. Трауберг. Сценаристы: Г. Козинцев, Л. Трауберг. Актеры: Е. Кузьмина, П.Соболевский, Д.Гутман, С.Герасимов, О.Жаков и др. Драма.

Торговцы славой. СССР, 1929. Режиссер Л. Оболенский. Сценаристы: Л.Оболенский, Н. Равич (авторы пьесы М. Паньоль, П. Нивуа). Актеры: В. Аксёнов, А. Судакевич, В. Барский, Я. Волков, А. Стэн и др. Драма.

1930

Кавказский пленник. СССР, 1930. Режиссер А. Ивановский . Сценаристы: П. Щёголев, В. Мануйлов. Актеры: Б. Тамарин, Г. Кравченко, А. Сандель (Санделль) и др. Мелодрама.

Мирабо. СССР, 1930. Режиссер и сценарист А.Кордюм. Актеры: П. Масоха, С.Минин, Л. Островская-Курдюм и др. Драма.

Обречение / Обреченные. СССР, 1930. Режиссеры: Л. Пуш, Д. Рондели. Сценаристы: Л. Пуш, Б. Щаранский. А. Гидони. Актеры: Г. Егорова-Доленко, Н. Коломенский, И. Марот и др. Военная драма. 
1931

Снайпер, СССР, 1931. Режиссер и сценарист С. Тимошенко. Актеры: П. Соболевский, Б. Шлихтинг, П. Кириллов, В. Гардин и др. Военная драма.

1932

Крылья. СССР, 1932. Режиссеры: И. Кравчуновский, М. Гоморов, Б.Юрцев. Сценарист А.Филимонов. Актеры: К. Градополов (ст.), А. Панкрышев, П. Рожицкий и др. Военная драма.

События в (городе) Сен-Луи. СССР, 1932. Режиссер М. Вернер. Актеры: И.Козлов, С.Мкртчян, В. Цоппи и др. Драма.

1934

Пышка. СССР, 1934. Режиссер и сценарист М. Ромм (экранизация новеллы Г. де Мопассана). Актеры: Г. Сергеева, А. Файт, А. Горюнов, Ф.Раневская, П. Репнин, Т. Окуневская и др. Драма.

1936

Гобсек. СССР, 1936. Режиссер Константин Эггерт. Сценаристы: Олег Леонидов, Константин Эггерт. Актеры: Леонид Леонидов, Александр Шатов, Галина Сергеева и др. Драма.

Дети капитана Гранта. СССР, 1936. Режиссер В. Вайншток. Сценарист О. Леонидов (автор романа - Ж. Верн). Актеры: Ю. Юрьев, И. Чувелев, Н. Черкасов, М. Стрелкова, Н. Витовтов, Я. Сегель и др. Приключенческая драма.

Зори Парижа. СССР, 1936. Режиссер Григорий Рошаль. Сценаристы: Григорий Рошаль, Георгий Шаховский. Актеры: Николай Плотников, Антонина Максимова, Андрей Абрикосов и др. Драма.

1937

Гаврош. СССР, 1937. Режиссер Татьяна Лукашевич. Сценарист Георгий Шаховский (по роману В. Гюго «Отверженные»). Актеры: Николай Сморчков, Иван Новосельцев, Нина Зорская и др. Драма.

1938

Юные коммунары. СССР, 1938. Режиссер Андрей Кустов. Сценарист Илья Рыжов. Актеры: А. Искандиаров, Константин Тыртов, Вера Орлова и др. Драма.

1939

Человек в футляре. СССР, 1939. Режиссер и сценарист И. Анненский (экранизация рассказа А.Чехова). Актеры: Н. Хмелев, М. Жаров, О. Андровская, В. Гардин, О. Абдулов, А. Грибов, Ф. Раневская и др. Комедия.

1941

Боевой киносборник № 7. СССР, 1941. Режиссеры: А. Гендельштейн, К. Минц, С. Юткевич, А. Роу, Л. Альцев, Р. Перельштейн. Сценаристы: М. Витухновский, М. Вольпин, К. Минц, А. Сазонов, Н. Эрдман, Д. Еремич, И. Маневич. Актеры: Э. Гарин, П. Оленев, Н. Охлопков, С. Мартинсон и др.

1942

Славный малый. СССР, 1942. Режиссер Б. Барнет. Сценаристы: А. Каплер, П. Павленко (автор повести "Мстители" П. Павленко). Актеры: Е. Григорьев, О. Якунина, Е. Сипавина, В. Добровольский, Н. Боголюбов и др. Комедия.

1944

Кутузов. СССР, 1944. Режиссер В. Петров. Актеры: А. Дикий, Н. Охлопков, С. Закариадзе и др. Военная драма. 
1945

Пятнадцатилетний капитан. СССР, 1945. Режиссер В. Журавлёв. Сценаристы: Г. Гребнер, В.Журавлёв. Актеры: В. Ларионов, А. Хвыля, М. Астангов и др. Приключенческая драма.

1946

Адмирал Нахимов. СССР, 1946. Режиссер В.Пудовкин. Сценарист И. Луковский. Актеры: А.Дикий, Е.Самойлов, В. Владиславский, В.Пудовкин и др. Военная драма.

Беспокойное хозяйство. СССР, 1946. Режиссер М. Жаров. Сценаристы: П. и Л. Тур. Актеры: Л. Целиковская, А. Граве, М. Жаров, В. Доронин, Ю. Любимов, В. Балашов, С. Филиппов и др. Комедия.

В дальнем плавании. СССР, 1946. Режиссер В. Браун. Сценарист Г. Колтунов. Актеры: А.Бучма, Б. Дмоховский, М.Высоцкий, М.Романов и др. Приключенческая драма.

1953

Адмирал Ушаков. СССР, 1953. Режиссер М.Ромм. Сценарист А.Штейн. Актеры: И. Переверзев, Г. Юдин, В. Дружников и др. Военная драма.

Корабли штурмуют бастионы. СССР, 1953. Режиссер М.Ромм. Сценарист А.Штейн. Актеры: И. Переверзев, Г. Юдин, В. Дружников, В.Балашов, С. Бондарчук, Г. Юматов и др. Военная драма.

1956

Поэт. СССР, 1956. Режиссер Б. Барнет. Сценарист В. Катаев. Актеры: Н. Крючков, И. Извицкая, С. Дворецкий, 3. Фёдорова и др. Драма.

Убийство на улице Данте. СССР, 1956. Режиссер М. Ромм. Сценаристы: Е. Габрилович, М. Ромм. Актеры: Е. Козырева, М. Козаков, Н. Комиссаров, М. Штраух, Р. Плятт и др. Драма.

1957

Без вести пропавший. СССР, 1957. Режиссер И. Шмарук. Сценарист В. Закруткин. Актеры: М. Кузнецов, С. Гиацинтова, Б. Индриксоне, Н. Ужвий и др. Драма.

Борец и клоун. СССР, 1957. Режиссеры: Б.Барнет, К. Юдин. Сценарист Н. Погодин. Актеры: С.Чекан, А.Михайлов , А. Соловьёв, Г.Вицин и др. Драма.

Рита. СССР, 1957. Режиссер А. Неретниеце. Сценарист Ф. Кнорре. Актеры: И. Гулбе, Э. Павулс, В. Зандбергс и др. Драма.

1959

Тоже люди. СССР, 1959. Режиссер и сценарист Г. Данелия. (экранизация отрывка из романа Л.Н. Толстого «Война и мир»). Актеры: Л. Дуров, М. Захариас, Е. Кудряшёв, В. Санаев, Г. Милляр и др. Военная драма.

1960

Леон Гаррос ищет друга / Vingt mille lieues sur la terre. СССР-Франция, 1960. Режиссер М. Пальеро. Сценаристы: Л. Зорин, С. Клебанов, М. Курно, С. Михалков. Актеры: Т. Самойлова, Ю. Белов, Л. Зитрон, Ж. Рошфор, Ж. Гавен, В. Зубков, Л. Марченко, В. Ивашов и др. Комедия.

Нормандия-Неман | Normandie-Niemen. CССР-Франция, 1960. Режиссер Ж. Древиль Сценаристы: Ш. Спаак, К. Симонов, Э. Триоле. Актеры: В. Доронин, Н. Лебедев, В. Бамдасов, В. Гусев, Н. Рыбников, Ю. Медведев, М. Кассо, Ж. Ривьер, Р. Менар и др. Военная драма.

Русский сувенир. СССР, 1960. Режиссер и сценарист Г. Александров. Актеры: Э. Гарин, А. Попов, П. Кадочников, Э. Быстрицкая, Л. Орлова, В. Авдюшко, А. Будницкая, В. Гафт, Э. Геллер и др. Комедия. 
1961

Две жизни. СССР, 1961. Режиссер Л. Луков. Сценарист А. Каплер. Актеры: Н. Рыбников, М. Володина, В. Тихонов, Э. Нечаева, С. Чекан, В. Дружников, Л. Свердлин, О. Жизнева, А. Ларионова, Г. Юматов и др. Драма.

Суд сумасшедших. СССР, 1961. Режиссер и сценарист Г. Рошаль. Актеры: В. Ливанов, И. Скобцева, В. Хохряков, В. Белокуров, А. Кончаловский, Л. Сухаревская, М. Козаков, Ю. Яковлев, М. Булгакова, Н. Бурляев и др. Драма, фантастика.

Украинская рапсодия. СССР, 1961. Режиссер С. Параджанов. Сценарист А. Левада. Актеры: О. Реус-Петренко, Э. Кошман, Ю. Гуляев, Н. Ужвий и др. Мелодрама.

1962

Гусарская баллада. СССР, 1962. Режиссер Э. Рязанов. Сценаристы: А. Гладков, Э. Рязанов. Актеры: Л. Голубкина, Ю. Яковлев, Н. Крючков, И. Ильинский, Т. Шмыга и др. Музыкальная комедия.

1964

Жаворонок. СССР, 1964. Режиссеры: Н. Курихин, Л. Менакер. Сценаристы: М. Дудин, С.Орлов. Актеры: В. Гуренков, Г. Юхтин, В. Погорельцев, В. Скулме, Б. Оя и др. Военная драма.

Зелёный огонёк. СССР, 1964. Режиссер В. Азаров. Сценарист В. Спирина. Актеры: А. Кузнецов, С. Савёлова, А. Папанов, Т. Бестаева, И. Рыжов, В. Санаев, В. Невинный, В. Ливанов, З. Фёдорова, Э. Геллер, А. Бордье, Ж.-М. Бордье и др. Драма.

1965

Война и мир. СССР, 1965-1967. Режиссер С. Бондарчук. Сценаристы: С. Бондарчук, В. Соловьёв (автор романа - Л. Толстой). Актеры: В. Тихонов, С. Бондарчук, Л. Савельева, О. Табаков, А. Кторов, А. Шуранова, А. Вертинская, И. Скобцева, В. Лановой, О. Ефремов, Э. Марцевич, Б. Захава, Н. Трофимов, Н. Рыбников, В. Стржельчик и др. Драма.

Гиперболоид инженера Гарина. СССР, 1965. Режиссер А. Гинцбург. Сценаристы И. Маневич, А. Гинцбург (автор романа - А.Толстой). Актеры: Е. Евстигнеев, Н. Климова, В. Сафонов, М. Астангов, В. Дружников, Б. Оя и др. Детектив. Фантастика.

Заговор послов. СССР, 1965. Режиссер Н. Розанцев. Сценаристы: М. Маклярский, Г. Курпнек, Н. Розанцев. Актеры: У. Думпис, В. Медведев, И. Класс, Р. Гладунко, О. Басилашвили, Л. Данилина, Э. Павулс, В. Сошальский и др. Детектив.

Третья молодость. СССР-Франция, 1965. Режиссеры: Ж. Древиль, И. Менакер. Сценаристы: А. Галич, П. Андреота. Актеры: Ж. Сегаль, О.Стриженов, Ж. Ферьер, Н. Величко, Н. Черкасов, Н. Трофимов, Г. Нилов, А. Ларионова, В. Стржельчик и др. Драма.

Эскадра уходит на запад. СССР, 1965. Режиссеры: М. Билинский, Н. Винграновский. Сценаристы: А.Левада, М. Билинский. Актеры: Э. Леждей, Н. Лазарева, А. Шестаков, С. Чекан, В. Шалевич, А. Файт и др. Драма.

1966

Ноктюрн. СССР, 1966. Режиссер Р. Горяев. Сценарист А.Станкевич (автор рассказа Ж.Грива). Актеры: П. Ракса, Г. Цилинский, О. Хабалов и др. Военная драма.

1967

Журналист. СССР, 1967. Режиссер и сценарист С. Герасимов. Актеры: Ю. Васильев, Г. Польских, Н. Федосова, И. Лапиков, С. Никоненко, С. Герасимов, Т. Макарова, В. Теличкина, Ж. Болотова, Е. Васильева, А. Вертоградов, Л. Овчинникова, В. Шукшин, А. Жирардо и др. Драма.

Разбудите Мухина! СССР, 1967. Режиссер Я. Сегель. Сценаристы: А. Гребнев, Я. Сегель. Актеры: Ч. Шакуров, Л. Алешникова, А. Пелеес и др. Комедия. 
1968

Далеко на Западе. СССР, 1968. Режиссер А. Файнциммер. Сценарист Г. Мдивани. Актеры: Н. Крючков, В. Сафонов, Н. Мерзликин, Г. Юхтин, Г. Плаксин, А. Вертоградов, В. Дворжецкий и др. Военная приключенческая драма.

Интервенция. СССР, 1968. Режиссер Г. Полока. Сценарист Л. Славин (автор пьесы - Л. Славин). Актеры: В. Высоцкий, В. Золотухин, О. Аросева, Г. Ивлиева, Е. Копелян, Р. Нифонтова, В. Татосов, Ю. Толубеев, В. Гафт, М. Хуциев и др. Комедия.

Ошибка Оноре де Бальзака. СССР, 1968. Режиссер Т. Левчук. Сценарист Н. Рыбак. Актеры: В. Хохряков, Р. Нифонтова, Я. Геляс, В. Скулме, Р. Недашковская, И. Дмитриев, И. Миколайчук, В. Заклунная и др. Мелодрама.

Это мгновение. СССР, 1968. Режиссер и сценарист Э. Лотяну. Актеры: М. Сагайдак, М. Волонтир, Х. Фернандес, М. Соцки-Войническу, С.Тома и др. Драма.

1969

Ватерлоо / Waterloo. СССР-Италия, 1969. Режиссер С. Бондарчук. Сценаристы: С. Бондарчук, В. Боничелли. Актеры: Р. Стайгер, К. Пламмер, О. Уэллс, С. Закариадзе, Е. Самойлов, О. Видов и др. Военная драма.

Сюжет для небольшого рассказа. СССР-Франция, 1969. Режиссер С. Юткевич. Сценарист Л. Малюгин. Актеры: Н. Гринько, М. Влади, И. Саввина, Р. Быков, Е. Лебедев, Е. Васильева и др. Мелодрама.

1970

Узники Бомона. СССР, 1970. Режиссер Ю. Лысенко. Сценаристы: Ю. Лысенко, Ж. Журибеда. Актеры: М. Голубович, О. Лысенко, Б.Кудрявцев и др. Военная драма.

1971

Комитет девятнадцати. СССР, 1971. Режиссер С. Кулиш. Сценаристы: С. Кулиш, С. Михалков, А. Шлепянов. Актеры: Н. Засухин, С. Смехнова, Ю. Ярвет и др. Драма.

Корона Российской Империи, или Снова Неуловимые. СССР, 1971. Режиссер Э. Кеосаян. Сценаристы: Э. Кеосаян, А. Червинский. Актеры: М. Метёлкин, В. Косых, В. Васильев, В. Курдюкова, И. Переверзев, А. Джигарханян, В. Ивашов, В. Стржельчик, Е. Копелян, В. Белокуров, Р. Быков, Я. Френкель, Л. Гурченко, А. Файт, Э. Кеосаян и др. Приключенческая комедия.

Освобождение. СССР-Югославия-Италия-Полыша, 1968-1971. Режиссер Юрий Озеров. Сценаристы: Юрий Бондарев, Юрий Озеров, Оскар Курганов. Актеры: Николай Олялин, Лариса Голубкина, Борис Зайденберг, Сергей Санаев, Владимир Самойлов, Юрий Каморный, и др. Драма.

1972

Четвертый. СССР, 1972. Режиссер и сценарист А. Столпер (автор повести К.Симонов). Актеры: В. Высоцкий, М. Терехова, С. Шакуров, А. Кайдановский, Ю. Соломин, Т. Васильева, М. Лиепа, А. Джигарханян, Ю. Будрайтис, Л. Дуров, Л. Круглый, 3. Славина, Л. Кулагин, М. Волонтир и др. Драма.

1973

Города и годы. СССР, 1973. Режиссер А. Зархи. Сценаристы: В. Валуцкий, А. Зархи (автор романа - К.Федин). Актеры: Б. Брыльска, И. Старыгин, 3. Глацедер, С. Мартинсон, И. Печерникова, Г. Бурков, Н. Гринько, Л. Кулагин, В. Носик и др. Драма.

Крах инженера Гарина. СССР, 1973. Режиссер Л. Квинихидзе. Сценарист С. Потепалов (автор романа - А.Толстой). Актеры: О. Борисов, А. Белявский, Н. Терентьева, А. Кайдановский, В. Никулин, Е. Копелян, А. Масюлис и др. Детектив.

1974

Кто, если не ты. СССР, 1974. Режиссер Г. Кузнецов. Сценарист И. Бондин. Актеры: Ф. Одиноков, М. Булгакова, Н. Сектименко, А. Беспалый и др. Драма. 
Соломенная шляпка. СССР, 1974. Режиссер и сценарист Л. Квинихидзе (автор пьесы - Э. Лабиш). Актеры: А. Миронов, В. Стржельчик, 3. Гердт, Е. Копелян, Е. Васильева, И. Кваша, Л. Гурченко, А. Фрейндлих, М. Козаков, А. Бениаминов и др. Музыкальная комедия.

1975

Бегство мистера Мак-Кинли. СССР, 1975. Режиссер М. Швейцер. Сценарист Л. Леонов. Актеры: Д. Банионис, Ж. Болотова, А.Степанова, Б. Бабочкин, А. Демидова, В. Высоцкий, А. Вокач, Л. Куравлев, Н. Волков, Т. Лаврова, А. Файт. Драма.

Воздухоплаватель. СССР, 1975. Режиссеры А. Вехотко, Н. Трощенко. Сценарист В. Кунин. Актеры: Л. Варфоломеев, Е. Васильева, В. Заманский, А. Джигарханян, В. Никулин, А. Равикович, В. Ильичёв, А. Солоницын, О. Басилашвили, Л. Мерзин, С. Дрейден и др. Драма.

Звезда пленительного счастья. СССР, 1975. Режиссер В. Мотыль. Сценаристы: М. Захаров, В. Мотыль, О. Осетинский. Актеры: И. Купченко, А. Баталов, Н. Бондарчук, О.Стриженов, Э. Шикульска, И. Костолевский, А. Пороховщиков, О. Янковский, В. Ливанов, И. Смоктуновский, В. Стржельчик, И. Дмитриев и др. Драма.

Капитан Немо. СССР, 1975. Режиссер В. Левин. Сценаристы: В. Левин, Э. Смирнов (автор романа «Двадцать тысяч лье под водой» Ж.Верн). Актеры: В. Дворжецкий, Ю. Родионов, М. Кононов, В. Талашко, М. Вертинская, В. Басов, Г. Нилов, А. Пороховщиков и др. Фантастика.

Под крышами Монмартра. СССР, 1975. Режиссер В. Гориккер. Сценаристы: В. Гориккер, Г. Рябкин, С. Болотин, Т. Сикорская (автор оперетты - «Фиалка Монмартра» И. Кальман). Актеры: Е. Симонова, В. Смелкова, А. Кайдановский, И. Старыгин, В. Носик, Л. Касаткина, В. Басов, О. Анофриев, А. Белявский, Э. Геллер и др. Музыкальная комедия, оперетта.

Ярослав Домбровский. СССР-Польша, 1975. Режиссер Б. Поремба. Сценарист Ю. Нагибин. Актеры: 3. Малянович, М. Потоцка, А. Калягин, В. Авдюшко, В. Ивашов, Е. Копелян, Л. Лужина, А. Пороховщиков, М. Козаков и др. Драма.

1976

Дервиш взрывает Париж. СССР, 1976. Режиссеры: Ш. Махмудбеков, К. Рустамбеков. Сценарист Э. Кулибеков (автор комедии «Мсье Жордан-ботаник и дервиш Мастали-шах» М. Ахундов). Актеры: С. Юрский, М. Бабаев, А. Искендеров и др. Комедия.

Красное и чёрное. СССР, 1976. Режиссер С. Герасимов. Сценаристы: С. Герасимов, Г. Склянский (автор романа - Стендаль). Актеры: Н. Ерёменко, Н. Бондарчук, Л. Марков, Н. Белохвостикова, Г. Стриженов и др. Мелодрама.

Небесные ласточки. СССР, 1976. Режиссер и сценарист Л. Квинихидзе (авторы оперетты «Мадемуазель Нитуш»: А. Мельяк, А. Мийо и Ф. Эрве). Актеры: А. Миронов, И. Нинидзе, Л. Гурченко, С. Захаров, А. Ширвиндт и др. Музыкальная комедия, оперетта.

Солдаты свободы. СССР - Болгария - Польша - Чехословакия - Венгрия - ГДР, 1976. Режиссер Ю. Озеров. Сценаристы: Ю. Озеров, О. Курганов и др. Актеры: С. Гецов, Б. Пасторек, Х. Пройскер, Я. Трипольский и др. Военная драма.

1977

Хождение по мукам. СССР, 1977. Режиссер В. Ордынский. Сценаристы: В. Ордынский, О. Стукалов-Погодин. Актеры: Ю. Соломин, И. Алфёрова, С. Пенкина, М. Ножкин, В. Езепов, М.Козаков, Л. Норейка и др. Драма.

1978

Мелодии одной оперетты / Бал в Савойе. СССР, 1985. Режиссер М. Ларин. (автор оперетты - П.Абрахам). Актеры: Н. Зейналова, А. Шейнин, Т. Тетерина и др. Музыкальная мелодрама. Оперетта.

Бархатный сезон. СССР-Швейцария, 1978. Режиссер В. Павлович. Сценаристы: Г. Горин, В. Павлович. Актеры: Ю. Будрайтис, Т. Сидоренко, А. Лазарев, С. Бондарчук, И. Смоктуновский, Н. Крючков, А. Масюлис и др. Драма. 
Д'Артаньян и три мушкетёра. СССР, 1978. Режиссер Г. Юнгвальд-Хилькевич. Сценарист М. Розовский (автор романа «Три мушкетера» - А.Дюма). Актеры: М. Боярский, В. Смехов, В. Смирнитский, И. Старыгин, О. Табаков, А. Фрейндлих, А. Трофимов, М. Терехова, А. Кузнецов, Л. Дуров, И. Алфёрова, Л. Каневский, Б. Клюев, В. Балон, Е. Цыплакова и др. Музыкальная приключенческая комедия.

Ярославна, королева Франции. СССР-Польша, 1978. Режиссер И. Масленников. Сценарист В. Валуцкий. Актеры: Е. Коренева, Н. Караченцов, К. Лавров, С. Мартинсон, А. Джигарханян, И. Дмитриев, В. Евграфов, В. Ливанов и др. Драма.

1979

Дюма на Кавказе. СССР, 1979. Режиссер Х. Хажкасимов. Сценарист Р. Габриадзе. Актеры: К. Себрис, В. Павлов, В. Этуш, И. Рыжов и др. Комедия.

Мнимый больной. СССР, 1979. Режиссер Л. Нечаев. Сценарист А. Червинский (автор пьесы - Ж.-Б.Мольер). Актеры: О. Ефремов, Н. Гундарева, А. Ромашин, Г. Беляева, Т. Васильева, Р. Быков, С. Садальский, А. Ширвиндт и др. Комедия.

Стакан воды. СССР, 1979. Режиссер и сценарист Ю. Карасик (автор пьесы Э.Скриб). Актеры: К. Лавров, А. Демидова, Н. Белохвостикова, С. Смирнова, И. Дмитриев и др. Мелодрама.

1980

Белый снег России. СССР, 1980. Режиссер Ю.Вышинский. Сценаристы: Ю. Вышинский, А. Котов (автор повести «Черные и белые» - А. Котов). Актеры: А. Михайлов, Н. Гундарева, В. Самойлов, Ю. Каюров, К. Миколаевска, А. Ромашин и др. Драма.

Братья Рико. СССР, 1980. Режиссер Г. Иванов. Сценарист В. Неделин (автор романа - Ж. Сименон). Актеры: Г. Бортников, А. Лицитис, С. Мартынов, Л. Чурсина, Г. Байкштите, А. Твеленева и др. Драма.

Ларец Марии Медичи. СССР, 1980. Режиссер Р. Фрунтов. Сценаристы: Е. Парнов, Р. Фрунтов (автор повести - Е. Парнов). Актеры: В. Рыжаков, К. Лучко, Э. Виторган и др. Детектив.

Однажды, двадцать лет спустя. Россия, 1980. Режиссер Ю. Егоров. Сценаристы: А. Инин, Ю. Егоров. Актеры: Н. Гундарева, В. Проскурин, Е. Лазарев, О. Ефремов, В. Титова, А. Потапов, И. Ясулович, В. Смирнитский, О. Гобзева, А. Чухрай, А. Юренев и др. Комедийная мелодрама.

Тифлис - Париж и обратно. СССР, 1980. Режиссер Л. Абашидзе. Сценаристы: Л. Абашидзе, Л. Челидзе. Актеры: Л. Абашидзе, Р. Эсадзе, К. Кавсадзе, Ф. Мкртчян и др. Комедия.

Тегеран-43. СССР, Франция, Швейцария, 1980. Режиссеры: А. Алов, В. Наумов. Сценаристы: А. Алов, В. Наумов, М. Шатров. Актеры: И. Костолевский, Н. Белохвостикова, А. Делон, К. Юргенс, А. Джигарханян, А. Филозов, Н. Гринько, Ж. Жере, К. Жад и др. Шпионский детектив.

Әскадрон гусар летучих. СССР, 1980. Режиссеры: Н. Хубов, С. Ростоцкий. Сценарист С. Ермолинский. Актеры: А. Ростоцкий, М. Шиманская, Л. Кузнецова, Е. Лебедев, Н. Ерёменко (мл.) и др. Приключенческая военная драма.

1981

Ленин в Париже. СССР, 1981. Режиссер С. Юткевич. Сценаристы: Е. Габрилович, С. Юткевич. Актеры: Ю. Каюров, К. Жад, В. Антоник, Б. Иванов, П. Кадочников и др. Драма.

Шофёр на один рейс. СССР, 1981. Режиссер В. Зобин. Сценарист А. Салынский. Актеры: Л. Федосеева-Шукшина, О. Ефремов, Л. Сухаревская, Н. Вавилова, Ю. Дуванов и др. Комедия.

1982

Жизнь Берлиоза / La vie de Berlioz. СССР-Франция, 1982. Режиссеры: Ж. Требута, В. Сергеев. Сценарист Ф. Буайе. Актеры: Д. Мезгиш, М. Кассовитц, Н. Алари и др. Драма. 
Ищите женщину. СCCP, 1982. Режиссер А. Сурикова (автор пьесы «Цыпленок и попугаиха» - Р.Тома). Актеры: С. Чиаурели, Л. Куравлёв, С. Юрский, Е. Соловей, А. Абдулов, Л. Ярмольник и др. Детектив.

Мать Мария. СССР, 1982. Режиссер и сценарист С. Колосов. Актеры: Л. Касаткина, Л. Марков, И. Горбачёв, В. Полонская, Е. Ханаева, В. Дворжецкий и др. Драма.

Принцесса цирка. СССР, 1982. Режиссер и сценарист С. Дружинина (автор оперетты - И. Кальман). Актеры: Н. Белохвостикова, И. Кеблушек, Н. Трофимов, Е. Шанина, Л. Касаткина, В. Басов, А. Ширвиндт и др. Музыкальная мелодрама (оперетта).

1983

Анна Павлова / Anna Pavlova. СССР, Великобритания, ГДР, Куба, Франция, 1983. Режиссер и сценарист Э. Лотяну. Актеры: Г. Беляева, Л. Булдакова, С. Шакуров, В. Ларионов, Дж. Фокс, Ж. Дебари и др. Драма.

Парижская драма. СССР, 1983. Режиссер и сценарист Н. Мащенко (автор новеллы «Паспорт для свободы» - Р. Твохи). Актеры: Е. Бондарчук, К. Цонев, Г. Гирдванис и др. Мелодрама.

1984

Багратион. СССР, 1985. Режиссеры: К. Мгеладзе, Г. Чохонелидзе. Сценаристы: В. Соловьёв, Г. Чохонелидзе. Актеры: Г. Чохонелидзе, Ю. Катин-Ярцев, М. Кузнецов, И. Малышева, И. Алфёрова, В. Дружников, П. Буткевич, В. Конкин, З. Кипшидзе и др. Военная драма.

Без семьи. СССР, 1984. Режиссер В. Бортко. Сценарист Н. Бортко (автор повести Г. Мало). Актеры: А. Васильев, С. Саркисян, Я. Хвилер, Е. Соловей, Э. Плешките и др. Драма.

Европейская история. СССР, 1984. Режиссер И. Гостев. Сценаристы Н. Леонов, И. Гостев. Актеры: В. Тихонов, Б. Тышкевич, Л. Филатов, Т. Акулова, А. Масюлис, В. Стржельчик, Ю. Будрайтис, С. Микульский и др. Драма.

Капитан Фракасс. СССР, 1984. Режиссер В. Савельев. Сценарист Ю. Визбор (автор романа - Т. Готье). Актеры: О. Меньшиков, М. Данилов, Ю. Ярвет, А. Исайкина, С. Тома и др. Мелодрама.

Медный ангел. СССР, 1984. Режиссер В. Дорман. Сценарист И. Кузнецов. Актеры: А. Кузнецов, И. Шевчук, В. Смирнитский, Л. Ярмольник, Л. Куравлёв, А. Филиппенко, Н. Ерёменко и др. Драма.

1985

Бал в Савойе. СССР, 1985. Режиссер и сценарист А.-Э. Керге (автор оперетты П. Абрахам). Актеры: Э. Кулль, А.-М. Юкскюла, Ю. Крюков и др. Музыкальная мелодрама. Оперетта.

Битва за Москву. СССР-Чехословакия-ГДР, 1985. Режиссер и сценарист Юрий Озеров. Актеры: Михаил Ульянов, Яков Трипольский, Александр Голобородько и др. Драма.

В поисках капитана Гранта. СССР-Болгария, 1985. Режиссер и сценарист С. Говорухин (автор романа «Дети капитана Гранта - Ж. Верн). Актеры: В. Смирнов, Н. Ерёменко, Л. Ульфсак, В. Гостюхин, Т. Акулова и др. Приключенческая драма.

Проделки Скапена. CCCP, 1985. Режиссеры: Г. Калатозов, М. Калатозишвили (автор пьесы - Ж.-Б.Мольер). Актеры: А. Гомиашвили, Г. Лордкипанидзе, Л. Антадзе и др. Комедия.

1986

Игра хамелеона. СССР, 1986. Режиссер и сценарист А. Жебрюнас (автор пьесы «Только правда» - Ж.-П. Сартр). Актеры: Г. Гладий, Ю. Будрайтис, И. Дапкунайте, Р. Адомайтис и др. Трагикомедия.

Капитан «Пилигрима». СССР, 1986. Режиссер А. Праченко. Сценарист А. Гусельников (автор романа «Пятнадцатилетний капитан» - Ж. Верн). Актеры: В. Ходченко, Н. Мгалоблишвили, А. Филозов, Т. Паркина, Л. Дуров, Л. Ярмольник и др. Приключенческая драма. 
Последняя дорога. СССР, 1986. Режиссер Л. Менакер. Сценаристы: Я. Гордин, Л. Менакер. Актеры: А. Калягин, В. Медведев, И. Купченко, И. Смоктуновский и др. Драма.

Путешествие мсье Перришона. СССР, 1986. Режиссер М. Микаэлян. Сценаристы: В. Валуцкий, М. Микаэлян (автор водевиля - Э. Лабиш). Актеры: О. Табаков, Т. Васильева, М. Зудина, И. Скляр, В. Гафт, Т. Догилева, А. Филиппенко, Е. Васильева и др. Комедия.

1987

Гардемарины, вперед! СССР, 1987. Режиссер С. Дружинина. Сценаристы: С. Дружинина, Ю. Нагибин, Н. Соротокина. Актеры: С. Жигунов, Д. Харатьян, В. Шевельков, T. Лютаева, О. Машная, М. Боярский, Е. Евстигнеев, В. Стржельчик, А. Абдулов, И. Смоктуновский и др. Приключенческая мелодрама.

Гобсек. СССР, 1987. Режиссер А. Орлов. Сценаристы: Г. Капралов, А. Орлов (автор повести - О. де Бальзак). Актеры: В. Татосов, С. Бехтерев, Б. Плотников, А. Будницкая, И. Костолевский и др. Драма.

Загадочный наследник. СССР, 1987. Режиссер и сценарист Т. Лисициан. Актеры: В. Ильин, И. Дапкунайте, И. Смоктуновский, И. Скобцева, Л. Броневой и др. Драма.

1988

Узник замка Иф. СССР, 1988. Режиссер Г. Юнгвальд-Хилькевич. Сценаристы: М. Захаров, Г. Юнгвальд-Хилькевич (автор романа «Граф Монте-Кристо» А. Дюма). Актеры: В. Авилов, А. Самохина, Е. Дворжецкий, М. Боярский, А. Лицитис, А. Жарков, А. Петренко и др. Приключенческая драма.

1989

Руанская дева по прозвищу Пышка. СССР, 1989. Режиссеры: Е. Гинзбург, Р. Мамедов. Сценарист К. Рыжов (автор рассказов Г. де Мопассан). М. Кикалейшвили, А. Абдулов, Л. Ярмольник, М. Полтева, Н. Лавров, С. Смирнова и др. Драма.

Руфь / Ruf. CССР-ФРГ, 1989. Режиссер В. Ахадов. Сценарист: Е. Козловский (автор пьесы - Е. Козловский). Актеры: А. Жирардо, И. Муравьёва, П. Семенихин, А. Петренко и др. Драма.

Сирано де Бержерак. СССР, 1989. Режиссер Н. Бирман. Сценарист А. Володин (автор пьесы - Э. Ростан). Актеры: Г. Гладий, О. Кабо, А. Подошьян, В. Ивченко и др. Драма.

Спаси и сохрани. Германия-СССР, 1989. Режиссер А. Сокуров. Сценарист Ю. Арабов (автор романа «Мадам Бовари» - Г. Флобер). Актеры: С. Зервудаки, Р. Вааб, А. Чередник и др. Драма.

1990

Все впереди. СССР, 1990. Режиссер и сценарист Н. Бурляев (автор романа В. Белов). Актеры: Т. Петрова, Б. Невзоров, В. Гостюхин, А. Ливанов, Л. Удовиченко, С. Сазонтьев, А. Пороховщиков, Т. Конюхова и др. Драма.

Попугай, говорящий на идиш. СССР-ФРГ, 1990. Режиссер и сценарист Е. Севела. Актеры: Р. Иоселиани, А. Леонтьев, М. Полицеймако, С. Фарада и др. Комедия.

1991

Мертвые без погребения, или Охота на крыс. СССР, 1991. Режиссер и сценарист И. Апасян (автор рассказа - Ж.-П. Сартр). Актеры: Е. Аминова, Л. Борисов, Е. Германова и др. Драма.

Портрет мадемуазель Таржи. СССР, 1991. Режиссер и сценарист В. Зобин (автор пьесы - И. Елагин). Актеры: А. Кузнецов, Л. Лютвинский, Р. Ткачук и др. Музыкальная комедия. 
1992

Белый король, красная королева / White King, Red Queen / Roi blanc, dame rouge. Россия-Франция-Германия, 1992. Режиссер С. Бодров. Сценаристы: С. Бодров, Г. Оганесян-Слуцки. Актеры: А. Дюссолье, Т. Васильева, В. Ильин, А. Жарков, Т. Кравченко, А. Ташков, А. Джигарханян и др. Драма.

Мушкетёры двадцать лет спустя. Россия, 1992. Режиссер Г. ЮнгвальдХилькевич. Сценаристы: Г. Николаев, Г. Юнгвальд-Хилькевич (автор романа - А.Дюма). Актеры: М. Боярский, В. Смехов, В. Смирнитский, И. Старыгин, В. Авилов, А. Равикович, А. Фрейндлих и др. Приключенческая драма.

Невеста из Парижа. Россия, 1992. Режиссер О. Дугладзе. Сценаристы: В. Константинов, Б. Рацер, О. Дугладзе. Актеры: А. Захарова, А. Соколов, Г. Польских и др. Комедия.

Тартюф. Россия, 1992. Режиссер Я. Фрид. Сценаристы: В. Константинов, Б. Рацер, Я. Фрид (автор пьесы Ж.-Б.Мольер). Актеры: М. Боярский, Л. Удовиченко, В. Стржельчик, И. Муравьёва, И. Скляр, А. Самохина, И. Дмитриев и др. Комедия.

1993

Дорога в рай / Die Strasse zum Paradies. Россия-ФРГ, 1993. Режиссер и сценарист В. Москаленко. Актеры И. Волков, Н. Петрова, Б. Ступка, А. Гуськов, А. Кортнев и др. Мелодрама.

Мадемуазель О. / Mademoiselle О. Россия-Франция, 1993. Режиссер Ж. Фулон. Сценаристы: С. Жокс, Ж. Фулон. Актеры: М. Наир, Е. Сафонова, А. Арбат и др. Драма.

Окно в Париж / Window to Paris / Salades russes. Россия-Франция, 1993. Режиссер Ю. Мамин. Сценаристы: А. Тигай, Ю. Мамин, В. Лейкин, В. Вардунас. Актеры: А. Сораль, С. Дрейден, В. Михайлов, Н. Усатова, А. Ургант и др. Комедия.

Проклятие Дюран. Россия, 1993. Режиссер В.Титов. Сценаристы: В. Титов, В. Вербин (автор романа «Похождения Рокамболя» - П. дю Террайль). Актеры: К. Рацер, О. Антонова, А. Нилов и др. Криминальная драма.

Тайна королевы Анны, или Мушкетёры тридцать лет спустя. Россия, 1993. Режиссер Г. Юнгвальд-Хилькевич. Сценаристы: Г. Николаев, Г. Юнгвальд-Хилькевич (автор романа «Виктонт де Бражелон» - А. Дюма). Актеры: М. Боярский, В. Смехов, В. Смирнитский, И. Старыгин, Д. Харатьян, А. Соколов, А. Фрейндлих, А. Равикович и др. Мелодрама.

1994

Любовь французская и русская. Россия, 1994. Режиссер и сценарист А. Александров. Актеры: Е. Дробышева, О. Шкловский, С. Колтаков и др. Мелодрама.

Простодушный. Россия, 1994. Режиссер Е. Гинзбург. Сценаристы: К. Рыжов, Е. Гинзбург (автор повести - Вольтер). Актеры: С. Маховиков, Л. Шахворостова, Л. Голубкина, А. Джигарханян и др. Музыкальная комедия.

Французский вальс. Россия, 1994. Режиссер С. Микаэлян. Сценаристы: Л.Аркадьев, С. Микаэлян. Актеры: И. Лачина, Д. Гибер, Р. Парти, И. Шведов и др. Мелодрама.

1995

Прибытие поезда. Россия, 1995. Режиссеры: Д. Месхиев, А. Хван, В. Хотиненко, А. Балабанов. Сценаристы: Д. Месхиев, А.Балабанов, А. Тигай, А. Детков, В. Залотуха, С. Сельянов. Актеры: С. Маковецкий, 3. Буряк, С. Стругачёв, А. Балабанов и др. Драма.

1996

Королева Марго. Россия, 1996. Режиссер А. Муратов. Сценарист М. Мареева (автор романа - А. Дюма). Актеры: Е. Добровольская, Д. Певцов, Е. Васильева, С. Юрский, М. Ефремов, Д. Харатьян, С. Жигунов, М. Боярский, Н. Караченцов, В. Сотникова и др. Драма. 
Линия жизни. Франция-Россия, 1996. Режиссер П. Лунгин. Сценаристы: П. Лунгин и др. Актеры: В. Перес, А. Джигарханян, А. Черкасова, Д. Певцов и др. Криминальная комедия.

Тысяча и один рецепт влюбленного кулинара. Франция-Грузия-БельгияРоссия-Украина, 1996. Режиссер Н. Джорджадзе. Сценарист И. Квирикадзе. Актеры: П. Ришар, М. Прель, Н. Киртадзе, Ж.-И. Готье и др. Комедия.

1997

Графиня де Монсоро. Россия, 1997. Режиссер В. Попков. Сценарист Е. Караваешникова (автор романа - А. Дюма). Актеры: Г. Мариани, А. Домогаров, Ю. Беляев, Е. Дворжецкий, К. Козаков, А. Горбунов, Д. Марьянов, Е. Стриженова и др. Драма.

1999

Восток-Запад / Est-Ouest. Франция-Украина-Россия-Испания-Болгария, 1999. Режиссер Р. Варнье. Сценаристы: Р. Ибрагимбеков, Л. Гардель, С. Бодров (ст.), Р. Варнье. Актеры: О. Меньшиков, С. Боннэр, С. Бодров (мл.), Т. Догилева, К. Денёв, Б. Ступка и др. Драма.

2000

Зависть богов. Россия, 2ооо. Режиссер В. Меньшов. Сценаристы: М. Мареева, В. Меньшов. Актеры: В. Алентова, А. Лобоцкий, А. Феклистов, Ж. Депардье, В. Павлов и др. Мелодрама.

Репете. Россия-Великобритания, 2ооо. Режиссер Е.Малевский. Сценаристы: В. Азерников, Е. Малевский. Актеры: В. Сторожик, А. Казанская, Е. Крюкова, В. Ларионов, В. Самойлов и др. Драма.

2001

Лиса Алиса. Россия-Франция, 2001. Режиссер Ж.-М. Карре. Сценаристы: В. Мережко, П. Лунгин. Актеры: Д. Волга, С. Мартынов, О. Сидорова, А. Черных, И. Алфёрова и др. Мелодрама.

Парижский антиквар. Россия, 20о1. Режиссер И. Шавлак. Сценаристы: А. Другов, Р. Белецкий. Актеры: И. Шавлак, А. Серебряков, И. Калныньш, С. Газаров, А. Белявский и др. Шпионский детектив.

Яды, или Всемирная история отравлений. Россия, 20о1. Режиссер К. Шахназаров. Сценаристы: К. Шахназаров, А. Бородянский. Актеры: И. Акрачков, О. Басилашвили, Ж. Дуданова, А. Баширов и др. Комедия.

2002

Дама в очках, с ружьём, в автомобиле. Россия-Латвия, 2оо2. Режиссеры: О. Бабицкий, Ю. Гольдин. Сценарист Е. Унгард (автор романа - С. Жапризо). Актеры: Т. Кузнецова, Э. Виторган, И. Леонова и др. Детектив.

2003

Русский ковчег. Россия-Германия, 2о03. Режиссер А. Сокуров. Сценаристы: А. Сокуров, Б. Хаимский, С. Проскурина, А. Никифоров. Актеры: С. Дрейден, М. Кузнецова, Л. Мозговой и др. Драма.

Тартарен из Тараскона. Россия, 2003. Режиссер Д. Астрахан. Сценарист: О. Данилов (автор романа - А. Доде). Актеры: А. Равикович, Е. Захарова, Н. Караченцов, И. Ульянова, А. Абдулов, А. Филиппенко и др. Комедия.

Француз. Россия, 2о03. Режиссер В. Сторожева. Сценарист И. Авраменко. Актеры: Т. Монфрай, М. Голубкина, И. Сукачев, Е. Вуличенко и др. Мелодрама.

Убойная сила-5. Россия, 20о3. Режиссеры: С. Снежкин, С. Осипьян, М. Брашинский. Сценаристы: А. Кивинов, О. Дудинцев. Актеры: К. Хабенский, А. Федорцов, Н. Фоменко, Ж. Депардье и др. Детектив. 
2004

Парижская любовь Кости Гуманкова. Россия, 20о4. Режиссер К. Одегов (автор повести - Ю. Поляков). Актеры: К. Одегов, С. Чуйкина, А. Терешко, Е. Стычкин и др. Мелодрама.

2005

Мой личный враг. Россия, 2о05. Режиссер В. Попков. Сценарист А. Волкова (автор романа Т. Устинова). Актеры: А. Большова, Д. Щербина, И. Гринёва, Э. Кюрдзидис, В. Смирнитский и др. Мелодрама.

Турецкий гамбит. Россия, 2о05. Режиссер Д. Файзиев. Сценаристы: Б. Акунин, Д. Файзиев. Актеры: Е. Бероев, О. Красько, А. Балуев, А. Лыков, В. Вержбицкий, Г. Куценко, Д. Певцов, Д. Ольбрыхский, Д. Бьенэме, В. Ильин, А. Гуськов и др. Детектив.

\section{6}

Очарование зла. Россия, 2оо6. Режиссер М. Козаков. Сценаристы: А. Бородянский, Н. Досталь, М. Козаков. Актеры: А. Серебряков, Н. Вдовина, Г. Тюнина, К. Бадалов, А. Каменкова, И. Васильев и др. Драма.

Парижане. Россия, 2оо6. Режиссеры: С. Полянский, С. Егерев. Сценарист В. Рогожкин. Актеры: П. Ришар, А. Мордвинова, И. Баголей и др. Комедия.

Пушкин: последняя дуэль. Россия, 2оо6. Режиссер и сценарист Н. Бондарчук. Актеры: с. Безруков, А. Снаткина, А. Ильин и др. Драма.

2007

Доярка из Хацапетовки. Россия-Украина, 20о7. Режиссер А. Гресь. Сценарист Т. Гнедаш. Актеры: Е. Осипова, К. Жандаров, В. Стержаков, Т. Назарова, Э. Кюрдзидис и др. Комедия.

\section{8}

Адмиралъ. Россия, 2оо8. Режиссер А.Кравчук. Сценарист В. Валуцикий. Актеры: К. Хабенский, Е. Боярская, А. Ковальчук, С. Безруков, В. Ветров, Е. Бероев, Р. Боринже и др. Мелодрама.

Всё могут короли. Россия, 2о08. Режиссер А. Черняев. Сценарист Э. Володарский. Актеры: Г. Куценко, Е. Полякова, О. Кучера, Ж. Депардье, Т.Васильева и др. Комедия.

Француз Сережа / Les Grandes Personnes. Россия-Франция, 20о8. Режиссер Т. Дюмон. Сценаристы: А. Глазков, С. Фричинская. Актеры: Д. Мороз, П. Баршак, Ф. Шовен и др. Мелодрама.

Я вернусь. Россия, 2оо8. Режиссер Е. Немых. Сценарист Н. Назарова. Актеры: Е. Боярская, Р.Полянский, Е.Подкаминская, Е. Николаева, А. Роговцева, Е.Васильева и др. Мелодрама.

\section{9}

Возвращение мушкетеров. Россия, 2009. Режиссер Г. Юнгвальд-Хилькевич. Сценаристы: Г. Юнгвальд-Хилькевич, А. Марков, Ю. Бликов. Актеры: М. Боярский, В. Смехов, В. Смирнитский, И. Старыгин, А. Макарский и др. Приключенческая комедия.

Кромовъ. Россия, 2оо9. Режиссер А. Разенков. Сценаристы: А. Разенков, К. Филимонов, М. Петухов. Актеры: В. Вдовиченков, К. Кутепова, А. Мордвинова, М. Горевой, А. Руденский и др. Драма.

Предел желаний. Россия, 20о9. Режиссер В. Дмитриевский. Сценаристы: Н. Михайлова, В. Дмитриевский. Актеры: Д. Шевченко, Е. Ксенофонтова, Д. Ульянов, О. Погодина, А. Легчилова, Р. Рязанова, Ю. Пересильд и др. Триллер.

\section{0}

Багровый цвет снегопада. Россия, 2о1о. Режиссер и сценарист В. Мотыль. Актеры: Д. Стоянович, М. Филиппов, А. Цуркан, А. Василевский, А. Белый и др. Драма.

Погоня за тенью. Россия, 2о10. Режиссеры Г.Киреева, В. Демент. Сценаристы: К.Закиров, В.Демент, А.Зензинов, В.Забалуев, О. Акимова, Ю. Гречаный. Актеры: К.Сафонов, И. Ефремова, Д.Матвеев, С.Громов, П. Бурель и др. Детектив. 
Прогулка по Парижу / Promenade 'a Paris. Россия-Франция, 2о10. Режиссер Д. Томашпольский. Сценарист Л. Темнова. Актеры: Е. Гусева, Э. Шимье, Л. Удовиченко, П. Хадсон и др. Мелодрама.

2011

Елки-2. Россия, 2011. Режиссеры: А. Баранов, А. Котт, Д. Киселёв, Л. Габриадзе. Сценаристы: Т. Бекмамбетов, Р. Непомнящий, О. Харина. Актеры: И. Ургант, С. Светлаков, И. Алфёрова, А. Петренко и др. Комедия.

Забытый. Россия, 2011. Режиссер В. Щегольков. Сценаристы: В. Зобин, В. Спиридонов (автор повести "Облдрамтеатр" А. Азольский). Актеры: Е. Цыганов, М. Машкова, А. Ильин, А. Серебряков, А. Мерзликин, Д. Мороз и др. Драма.

Краткий курс счастливой жизни. Россия, 2о11. Режиссер В. Гай Германика. Сценарист А.Козлова. Актеры: С. Ходченкова, К. Громова, А. Хазанова, А. Слю, К. Сафонов, К. Жандаров, К. Гацалов, И. Хакамада, В. Гай Германика, Е. Папанова, К. Собчак, Р. Зверь, Т. Лютаева, П. Роллен и др. Драма.

Я дождусь / J'attendrai. Беларусь-Россия-Франция, 2011. Режиссер И.Соловов. Сценаристы: А. Курейчик, А. Онищенко. Актеры: Ж. Давис, А. Пампушный, Е. Лядова, А. Миклош, Ф. де Сталь, Ж.-М. Фонбонн и др. Мелодрама.

2012

1812: Уланская баллада. Россия, 2012. Режиссер О. Фесенко. Сценарист Г. Шпригов. Актеры: С. Безруков, А. Соколов, А. Чиповская, А. Белый и др. Боевик.

Патруль. Васильевский остров. Россия, 2о12. Режиссер Е. Семёнов. Сценаристы: В. Голов, В. Дьяченко, Е. Семёнов. Актеры: К. Воробьёв, С. Алимпиев, А. Ведерников и др. Комедия.

Поддубный. Россия, 2012. Режиссер Г. Орлов. Сценарист Ю. Коротков. Актеры: М. Пореченков, К. Шпица, А. Михайлов, Р. Мадянов и др. Драма.

Ржевский против Наполеона. Россия, 2о12. Режиссер М. Вайсберг. Сценаристы: А. Яковлев, М. Савин. Актеры: П. Деревянко, В. Зеленский, С. Ходченкова и др. Комедия.

С Новым годом, мамы! Россия, 2012. Режиссеры: А. Аксененко, Д. Грачёв, К. Поплавский, А. Борматов, С. Андреасян. Сценаристы: Т. Бакумянц, Л. Марголин, О. Антонова, А. Маркин, Э. Никогосян, С.Андреасян. Актеры: Е. Вилкова, С. Иванова, Т. Васильева, А. Делон и др. Комедия.

2013

Василиса. Россия, 2013. Режиссер А. Сиверс. Сценаристы: А. Варданян, О. Маловичко, Д. Месхиев, А. Сиверс. Актеры: С. Ходченкова, Д. Соломыкин, Ж. Кузан и др. Драма.

Продавец игрушек. Россия, 2013. Режиссер Ю. Васильев. Сценарист В. Добросоцкий. Актеры: Ш. Хаматов, А. Дитковските, Т. Лютаева, П. Ришар, В. Смехов и др. Комедия.

три муикетёра. Россия, 2013. Режиссер С. Жигунов. Сценаристы: С. Жигунов, А. Житков (автор романа А. Дюма). Актеры: Р. Мухаметов, Ю. Чурсин, А. Макаров, П. Баршак, Ф. Янковский, М. Миронова, К. Лавроненко, В. Лановой, А. Лъков, А. Воробъёв, В. Раков, В. Этуи и др. Приключенский боевик.

Французский шпион. Россия, 2013. Режиссер А. Феоктистов. Сценарист Б. Миловзоров. Актеры: О. Кучера, Д. Супонин, Е. Редько и др. Шпионский детектив.

2014

Виктор / Viktor. Россия-Франция, 2014. Режиссер и сценарист Ф. Мартинес. Актеры: Ж. Депардье, Э. Хёрли, М. Маццарелло, А. Петренко, Д.Карасёв и др. Триллер.

Душа шпиона. Россия, 2014. Режиссер В. Бортко. Сценаристы: В. Бортко, М. Любимов. Актеры: А. Чернышов, К. Бродская, Ф. Бондарчук, Д. Спиваковский, М. Александрова, М. МакДауэлл, С. Боннэр, А. Булдаков, А. Джигарханян, А. Панин и др. Шпионский детектив. 
Екатерина. Россия, 2014. Режиссеры: А. Баранов, Р. Сабитов. Сценарист А. Алиев. Актеры: М. Александрова, Ю. Ауг, А. Яценко, Р. Мухаметов, И. Шосниг, П. Роллен и др. Драма.

Зайцев + 1. Россия, 2014. Режиссеры: М. Пежемский, В. Бродский, М. Старчак. Сценаристы: Д. Косяков, Е. Никишов и др. Актеры: Ф. Котов, М. Галустян, Н. Костенева, Ж. Депардье и др. Комедия.

Красивая жизнь. Россия, 2014. Режиссер А. Замятин. Сценарист В. Костина. Актеры: М. Митрофанова, Е. Шириков, А. Муцениеце, В. Ветров, Е. Цыплакова и др. Мелодрама.

Кухня в Париже. Россия, 2014. Режиссер Д. Дьяченко. Сценаристы: Д. Ян, В. Куценко, П. Данилов, И. Тудвасев, В. Шляппо. Актеры: Д. Назаров, М. Богатырёв, Е. Подкаминская, Д. Нагиев, О. Табаков, В. Перес и др. Комедия.

2015

Истребители. Последний бой. Россия, 2015. Режиссер 3. Ройзман. Сценаристы: Ю. Коротков, Г. Головенкин, А. Высоковский, Л. Порохня, 3. Ройзман. Актеры: Д. Дюжев, М. Андреева, Д. Арбенин, Д. Константинов, О. Судзиловская, А. Макеева, П. Бурель и др. Драма.

Поездка к матери. Россия-Франция, 2015. Режиссер и сценарист М. КосыревНестеров. Актеры: А. Экзаркопулос, А. Алексеев и др. Мелодрама.

Снайпер: герой сопротивления. Россия-Белоруссия, 2015. Режиссер А. Геворгян. Сценарист Г. Шпригов. Актеры: Г. Куценко, А. Снаткина, В. Гостюхин, Д. Бургазлиев, Д. Мартенс и др. Драма.

Таинственная страсть. Россия, 2015. Режиссер В. Фурман. Сценарист Е. Райская (автор романа В. Аксенов). Актеры: А. Морозов, Ю. Пересильд, Ч. Хаматова, Ф. Янковский, Е. Павлов, А.Ильин, А. Агопьян, Л. Кулагин, В. Фурман, Г. Тараторкин, С. Безруков, С. Заика и др. Драма.

2016

Вечный отпуск. Россия-Украина, 2016. Режиссер В. Власова. Сценаристы: Д. Зверьков, А. Мухортов, К. Маньковский, А. Смилянская, И. Филиппов, Т. Мастич, А. Ильков, И. Шишман, В. Буханцев, Г. Рубинштейн, Д. Торманов, А. Ильиных, К. Яровицын. Актеры: К. Крюков, В. Федорович, Я. Цапник, Д. Астрахан, П. Бурель и др. Комедия.

Выйти замуж за Пушкина. Россия, 2016. Режиссеры: В. Краснопольский, В. Усков. Сценарист М. Сапрыкина. Актеры: А. Бортич, Д. Гудочкин, Р. Мадянов, В. Мищенко, В. Андреев, Е. Семёнова, В. Шиловский, И. Добронравов, Л. Германова, П. Бурель и др. Комедийная мелодрама.

Герой. Россия, 2016. Режиссер Ю. Васильев. Сценаристы: О. Погодина-Кузмина, Н. Дорошкевич. Актеры: Д. Билан, С. Иванова, А. Балуев, М. Башаров, Ю. Пересильд, В. Ветров, Т. Лютаева, А. Адабашьян и др. Драма.

Колодец забытых желаний. Россия, 2016. Режиссер и сценарист П. Амелин (экранизация романа Т. Устиновой). Актеры: П. Трубинер, И. Горячева, Г. Некрасов и др. Детектив.

Петербург. Только по любви. Россия, 2016. Режиссеры: Р. Литвинова, А. Пармас, О. Бычкова, А. Гог, Н. Кудряшова, Н. Назарова, А. Смирнова. Сценаристы: Р. Литвинова, А. Пармас и др. Актеры: С. Заика, Я. Сексте, У. Добровская, Р. Литвинова, В. Горчаков и др. Мелодрама.

Пушкин. Россия, 2016. Режиссер А. Сахелашвили. Сценаристы: И. Баранов, А. Носков, В. Разгоев. Актеры: А. Молочников, С. Устинова, Я. Цапник, А. Бурковский, С. Муравьёв, П. Бурель и др. комедия.

Рай / Paradise/ Paradies. Германия-Россия, 2016. Режиссер А. Кончаловский. Сценаристы: Е. Киселёва, А. Кончаловский. Актеры: Ю. Высоцкая, К. Клаус, Ф. Дюкен и др. Драма. 
2017

Доктор Анна. Россия, 2017. Режиссер Ю. Лейзеров. Сценаристы: Ю. Смирнов, Э. Чурюмова, Д. Терехов. Актеры: К. Андоленко, Д. Дунаев, А. Комиссаров и др. Мелодрама.

Мата Хари. Португалия-Россия-Украина, 2017. Режиссеры: Д. Берри, Д. Берг, О. Ряшина. Сценаристы: И. Тер-Карапетов, О. Кириллов, Д. Берри. Актеры: В. Джоканте, О. Стак, Дж. Корбетт, М. Матвеев, В. Исакова, К. Раппопорт, К. Ламберт, А. Гуськов, Р. Хауэр, Ж. Депардье и др. Драма.

Охота на дьявола. Россия, 2о17. Режиссер Д. Ткебучава. Сценаристы: Д. Карышев, А.Турбин, В. Подорожнова. Актеры: С. Безруков, М. Луговая, Н. Швец, Е. Стычкин, А. Руденский, П. Роллен и др. Детектив.

Составитель фильмографии: Александр Федоров 